OPEN ACCESS

Edited by:

Jessica E. Frith,

Monash University, Australia

Reviewed by:

Asim Ejaz,

University of Pittsburgh, United States

Fábio G. Teixeira,

University of Minho, Portugal

${ }^{*}$ Correspondence:

Tara Karnezis

tkarnezis@svi.edu.au

${ }^{\dagger}$ These authors share first authorship

Specialty section:

This article was submitted to Translational Pharmacology,

a section of the journa

Frontiers in Pharmacology

Received: 30 September 2019 Accepted: 06 February 2020

Published: 03 March 2020

Citation:

Shukla L, Yuan Y, Shayan R, Greening DW and Karnezis T (2020) Fat Therapeutics: The Clinical Capacity of Adipose-Derived Stem Cells and Exosomes for Human Disease and

Tissue Regeneration.

Front. Pharmacol. 11:158.

doi: 10.3389/fphar.2020.00158

\section{Fat Therapeutics: The Clinical Capacity of Adipose-Derived Stem Cells and Exosomes for Human Disease and Tissue Regeneration}

\author{
Lipi Shukla ${ }^{1,2 \dagger}$, Yinan Yuan ${ }^{1 \dagger}$, Ramin Shayan ${ }^{1,2,3,4}$, David W. Greening ${ }^{5,6}$ \\ and Tara Karnezis ${ }^{1 *}$ \\ ${ }^{1}$ O'Brien Institute Department, St Vincent's Institute for Medical Research, Fitzroy, VIC, Australia, ${ }^{2}$ Department of Plastic \\ Surgery, St Vincent's Hospital, Fitzroy, VIC, Australia, ${ }^{3}$ Plastic, Hand and Faciomaxillary Surgery Unit, Alfred Hospital, \\ Prahran, VIC, Australia, ${ }^{4}$ Department of Plastic and Reconstructive Surgery, Royal Melbourne Hospital, Parkville, VIC, \\ Australia, ${ }^{5}$ Molecular Proteomics, Baker Heart and Diabetes Institute, Melbourne, VIC, Australia, ${ }^{6}$ Department of \\ Biochemistry and Genetics, La Trobe Institute for Molecular Science, La Trobe University, Bundoora, VIC, Australia
}

Fat grafting is a well-established surgical technique used in plastic surgery to restore deficient tissue, and more recently, for its putative regenerative properties. Despite more frequent use of fat grafting, however, a scientific understanding of the mechanisms underlying either survival or remedial benefits of grafted fat remain lacking. Clinical use of fat grafts for breast reconstruction in tissues damaged by radiotherapy first provided clues regarding the clinical potential of stem cells to drive tissue regeneration. Healthy fat introduced into irradiated tissues appeared to reverse radiation injury (fibrosis, scarring, contracture and pain) clinically; a phenomenon since validated in several animal studies. In the quest to explain and enhance these therapeutic effects, adipose-derived stem cells (ADSCs) were suggested as playing a key role and techniques to enrich ADSCs in fat, in turn, followed. Stem cells - the body's rapid response 'road repair crew' - are on standby to combat tissue insults. ADSCs may exert influences either by releasing paracrinesignalling factors alone or as cell-free extracellular vesicles (EVs, exosomes). Alternatively, ADSCs may augment vital immune/inflammatory processes; or themselves differentiate into mature adipose cells to provide the 'building-blocks' for engineered tissue. Regardless, adipose tissue constitutes an ideal source for mesenchymal stem cells for therapeutic application, due to ease of harvest and processing; and a relative abundance of adipose tissue in most patients. Here, we review the clinical applications of fat grafting, ADSC-enhanced fat graft, fat stem cell therapy; and the latest evolution of EVs and nanoparticles in healing, cancer and neurodegenerative and multiorgan disease.

Keywords: adipose, stem cell, exosome, extracellular vesicles, regeneration 


\section{INTRODUCTION}

Adipose dysregulation is fundamental to several important human disease states, such as obesity, chronic lymphedema and lipedema. In contrast to the unwanted effects of excess adipose tissue accumulation, however, adipose tissue also plays a critical physiological role (Fujimoto and Parton, 2011; Rajabzadeh et al., 2019). In humans, fat performs key functions, including energy storage and metabolism, thermoregulation, shock absorption and hormone metabolism (Nishimura et al., 2000; Yoshimura K, 2010). In addition, clinical use of fat tissue has revealed important potential therapeutic applications for adipose tissues in the treatment of human disease (Nishimura et al., 2000; Yoshimura K, 2010). Whilst the clinical use of fat initially began as a physical 'space filler' or 'contour correction' technique, it was through serendipitous observation of the tissues being filled with fat, that an even more important role has emerged - the role of adipose tissue as a putative therapeutic (Matsumoto et al., 2006).

An adipose derived stem cell (ADSC) is defined as a mesenchymal cell within adipose tissue with multipotent differentiation and self-renewal capacity. Adult stem cells have found an important role in tissue engineering and regenerative medicine, as they may be used to develop novel treatment approaches (Rajabzadeh et al., 2019). In particular, ADSCs are a most promising cell type for translational potential and for cellbased regenerative therapies, as they provide a new and unique source for multipotent stem cells that boasts ease and reproducibility of isolation using minimally invasive techniques with low morbidity. As multipotent ADSCs can differentiate into various cell types of the tri-germ lineages, including osteocytes, adipocytes, neural cells, vascular endothelial cells, cardiomyocytes, pancreatic $\beta$-cells, and hepatocytes; the use of fat/ADSCs and their cell products represents a paradigm of tissue regeneration and cell restoration.

Here, we review the treatment of human diseases using adipose tissue from its origins as the humble fat graft, through attempts to enrich the concentration of ADSCs within the grafts; to selective attempts to harness the potential paracrine effects of the ADSC secretome, and finally to the most recent evolution the targeted use of ADSC exosomes (now known as EVs). We provide a review of the field to date, exploring the therapeutic application of ADSCs and small EVs as delivery vehicles of the ADSC secretome for clinical use in disease. As the focus of the review is ADSC cell products, previous theories of fat differentiating or homing in to replace tissue as 'building blocks', are not extensively addressed.

\section{Fat Grafting, the Stromal Vascular Fraction and ADSCs \\ Fat Embryology, Anatomy and Physiology}

Adipocytes that form adipose tissue arise from perivascular adipoblast stem cells in the third month of gestation (Matsumoto et al., 2006) via adipocyte precursors, which, in turn, differentiate into mature fat cells (Joseph et al., 2002). After adolescence, minimal new adipocytes are formed, and the role of fat cell replication, is thereafter undertaken by post-adipocytes. The ultimate number of fat cells formed is genetically determined, and slightly influenced by environment and nutrition (Fujimoto and Parton, 2011).

Within adipose tissue, lipid droplets may be uni- or multiloculated (Fujimoto and Parton, 2011). Unilocular signet-ring shaped fat cells (25-200 $\mu \mathrm{m}$ diameter) are characteristic of 'white' fat. Multilocular cells, typically found in so-called 'brown' or 'beige' fat, consist of numerous smaller $(60 \mu \mathrm{m})$ fat droplets (Joseph et al., 2002). Brown fat occurs in smaller quantities near the thymus and in dorsal midline region of the thorax, neck and abdomen (Nueber, 1893; Fujimoto and Parton, 2011) and plays a role in regulating body temperature via non-shivering thermogenesis, a mitochondrial mechanism of heat generation via a specific carrier called an uncoupling protein (Czerny, 1895; Joseph et al., 2002). In contrast, white fat performs three distinct functions of heat insulation, mechanical cushioning, and an energy source/storage sync; (Illouz, 1986; Joseph et al., 2002). Fat for clinical therapeutic use is sourced predominantly from areas of white fat.

Adipocytes have two different catecholamines receptors (lipolytic $\beta-1$ receptors that secrete lipase and $\alpha-2$ receptors which block lipolysis) (Joseph et al., 2002). During weight gain, fat deposition occurs throughout the subcutaneous and visceral areas relatively evenly (Joseph et al., 2002), into existing adipocytes (hypertrophic growth) (Fujimoto and Parton, 2011). In contrast, when a patient is greater than thirty percent above the ideal weight (body mass index (BMI) over thirty-five), new fat cells are produced (hyperplastic obesity) (Fujimoto and Parton, 2011). Hyperplastic cells are more resistant to dieting and exercise (Tabit et al., 2012). During weight loss, visceral fat is preferential lost, due to greater sensitivity to lipolytic stimulation signals (Joseph et al., 2002). This a process associated with improved insulin resistance (Ross et al., 2014). Bariatric surgery reduces both visceral and subcutaneous fat, leading to overall improved metabolic profiles (Rajabzadeh et al., 2019), however surgery to remove subcutaneous fat (liposuction or abdominoplasty) do not lead to improved metabolic profiles (Ross et al., 2014). The largest amount of visceral fat occurs at level of umbilicus and the greatest amount of subcutaneous fat is found in the region of the buttocks; however, these distributions may vary significantly with gender (Mizuno, 2009). The abdomen and buttocks are the most commonly used areas for fat harvest for fat graft surgery (Ross et al., 2014).

\section{The History and Evolution of Fat Grafting}

An autologous graft is defined as the transfer of a tissue(s) to a distant area of the body, without its original blood supply (Nishimura et al., 2000) (Figure 1A). In order to survive, therefore, a fat graft needs to gain nutrients and a blood supply and from the native tissue bed into which it has been introduced. It needs early revascularization to avoid death of the grafted tissue (Nishimura et al., 2000; Yoshimura K, 2010). Unfortunately, due to poor graft re-vascularization, cell apoptosis or fat cell necrosis, up to $50 \%-100 \%$ of the initial injected volume may fail to engraft and become resorbed (Matsumoto et al., 2006). 


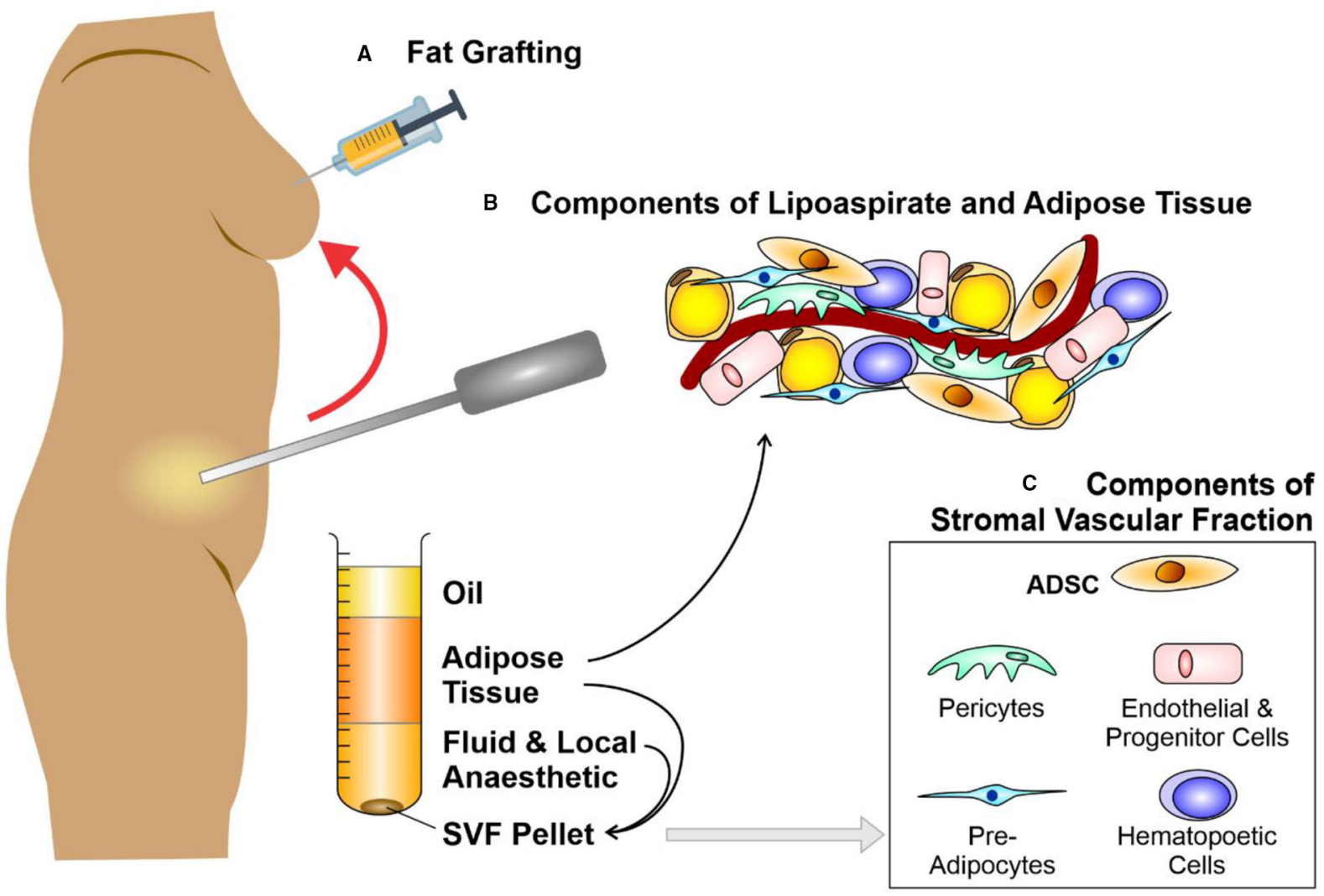

FIGURE 1 | Liposuction, fat grafting and the components of adipose tissue. Schematic diagram depicting (A) fat grafting after liposuction of subcutaneous fat from an abdominal donor site. The components of lipoaspirate (B) separate into layers of oil (discarded), aspirated adipose tissue and infranatant (composed of blood, plasma, and local anesthetic). The components of adipose tissue and the key constituents of the stromal vascular fraction (SVF) pellet (C) may be re-introduced to enhance the fat graft. Further processing of this adipose tissue with collagenase digestion and centrifugation allows the isolation of a SVF pellet. Figure adapted from Shukla et al. (2015) under the CC-BY license (Shukla et al., 2015).

Fat graft surgery was first performed by Neuber (1893), then expanded to breast reconstruction when a lipoma (benign fatty lesion) was transferred from the back to reconstruct a breast after cancer surgery (Czerny, 1895). By the 1980s, early rates of graft take [(approximately 50\% (Illouz, 1986)] had failed to significantly improved, despite multiple technical refinements in graft harvest, centrifuge or infiltration (Carraway and Mellow, 1990). Irrespective of these loss rates, liposuction techniques using syringe harvest enhanced the popularity of fat grafting for correcting facial contour defects in the 1980s (Rohrich et al., 2004) and led to the introduction of fat grafting for the correction of soft tissue deficits in other body areas (Coleman, 2001; Yoshimura et al., 2008; Tabit et al., 2012; Ross et al., 2014) (Figures 1A, B). Nevertheless, significant numbers of patients who underwent fat grafting continued to suffer graft loss, and those in whom graft take was achieved endured up to $70 \%$ loss of volume (Matsumoto et al., 2006; Mizuno, 2009).

More recently, fat grafting has been used in staged breast reconstruction following oncological mastectomy, and has been adapted in some settings, to a single-stage, large volume injection procedure (Khouri R, 2009). Various authors have suggested differing methods of injection for achieving optimal graft take, ranging from individual droplet deposits (the so-called pearling technique) to a multilayered and multidirectional lattice configuration as an adaptation to the pre-existing standard 3 $\mathrm{mm}$ linear graft injections techniques (Coleman, 2001).

Overall, no consensus had been reached regarding the optimal technical procedure to maximize graft take. Whilst the nuances have been debated, the basic principle is that adipose tissues are removed from beneath the skin via minimal-access incisions using a hollow, blunt-ended but perforated steel surgical tube, attached to a source of external suction and collection reservoir.

\section{Principles of Fat Grafting, Graft Enhancement and Treatment With ADSCs}

Several technical modifications have been described to enhance fat graft reliability. It has been suggested that graft survival occurs through imbibition then angiogenesis (Kilroy et al., 2007) from surrounding tissues, promoted through hypoxic-driven protein growth factors. Therefore, various additions such as collagen, FGF, and insulin (Hong et al., 2010; Baek et al., 2011) were suggested to enhance adipocyte survival; however, did not result 
in significant graft survival gains. The skin quality overlying areas of fat injection were anecdotally observed to improve, therefore, it was suggested that this may be an influence of stem cells within the introduced adipose cell population (Rigotti et al., 2007). The mesenchymal stem cells (MSCs) thought to be instrumental in these effects were hypothesized to originate from pre-adipocytes (ADSCs) within the stromal vascular fraction (SVF) of liposuction aspirate (Gimble et al., 2011); or from MSCs derived from blood vessels (Eto et al., 2011).

Regardless, of all the different variables in fat grafting, the concept of multipotent stem cells populating fat grafts became the new justification for the use of fat graft. ADSCs became the central focus of enhancing grafts and lately, a potential factor in reversing tissue injury, such as injury occurring in radiotherapy (Haubner et al., 2013). ADSCs were initially isolated nearly 2 decades ago by Zuk and colleagues (Zuk et al., 2001). Eto et al. suggested that ADSCs had lower metabolic demands and were more resistant to the mechanical trauma of fat grafting (Yoshimura et al., 2009; Eto et al., 2012; Trojahn Kolle et al., 2012), and were thus more robust compared to adipocytes (Zuk et al., 2001; von Heimburg et al., 2005; Shoshani et al., 2005; Lu et al., 2009; Tremolada et al., 2010; Suga et al., 2010; Piccinno et al., 2013). Other authors showed enhance graft survival rates due to greater levels of angiogenesis (via either imported endothelial progenitor cells or ADSCs) generating neo-vasculature (Thanik et al., 2009; Zhu et al., 2010; Kolle et al., 2013). Butala et al. on the other hand, postulated that ADSCs in a graft may themselves chemotactically recruit further stem cells, particularly from bone marrow, or differentiate into fat cells themselves (Zhu et al., 2010; Butala et al., 2010; Kolle et al., 2013).

To enhance the abundance of ADSCs within fat grafts (Caplan AI, 2006; Eto et al., 2012; Kolle et al., 2013; Wang et al., 2013) Yoshimura et al. proposed "cell-assisted lipotransfer enrichment" in which the surplus lipoaspirate was separated into components by centrifugation and the lipoaspirate supplemented with additional SVF (Matsumoto et al., 2006; Fraser et al., 2006; Yoshimura et al., 2008; Yoshimura K, 2010; Harfouche and Martin, 2010; Rigotti et al., 2010; Krumboeck et al., 2013). Briefly, SVF [comprised of 10\% ADSCs (Zhu Y et al., 2008; Tabit et al., 2012; Akita et al., 2012)] is derived from a lipoaspirate component that is surplus to the volume needed to fill a particular soft-tissue deficit (Ross et al., 2014). Subsequent to digestion with collagenase, centrifugation creates an SVF pellet (Figure 1C). Eventually, the SVF pellet is introduced to the lipoaspirate, in readiness for injection with the ADSCs as part of a fat graft (Zuk et al., 2001; Kilroy et al., 2007; Mizuno, 2009; Yoshimura et al., 2009; Yoshimura K, 2010; Tremolada et al., 2010; Trojahn Kolle et al., 2012; Hsiao et al., 2012). A randomized control trial was designed by Kolle et al. to assess enrichment of lipoaspirate with ADSC concentrations of up to 2,000 times over physiological levels (Kim et al., 2009). Quantification using magnetic resonance scans suggested that ADSC-enriched groups yielded higher graft retention volumes (Caplan AI, 2006; Kolle et al., 2013).

Collectively, this work implied that enrichment of fat grafts could increase viability, volume retention, and neovascularization, whilst reducing necrosis rates. The findings also supported the theory that adding ADSCs may augment fat graft survival by bolstering adipogenesis, the supporting vasculature and/or diminishing cell apoptosis-key features of the regenerative properties of fat graft (Phinney and Prockop, 2007; Zhu et al., 2010; Collawn et al., 2012; Kolle et al., 2013).

\section{Characteristics of ADSCs}

ADSCs are defined as plastic-adherent cells (in standard culture conditions) (Dominici et al., 2006; Zimmerlin et al., 2011), cells exhibiting a $\mathrm{CD}_{4}^{+}, \mathrm{CD}^{-}$, and $\mathrm{CD}^{-} 5^{-}$cell surface marker profile (Gronthos et al., 2001; Shayan et al., 2006; Yoshimura et al., 2006; Karnoub et al., 2007; Walter et al., 2009; Lin et al., 2010; Zimmerlin et al., 2011; AIHW, A, 2012; Authors on behalf of, I et al., 2012; Baer and Geiger, 2012; Zuk, 2013) and cells showing differentiation multi-potency into mature bone, cartilage, and fat (Zuk PA1 et al., 2002).

In adults, stem cells may uniquely differentiate into more specialized cell types to: i) replenish injured cells, ii) preserve tissue integrity, iii) maintain cell homeostasis during normal growth or healing (Caplan AI, 2006; Kim et al., 2009). Therefore, MSCs show promising utility in tissue regeneration (Ebrahimian et al., 2009; Harfouche and Martin, 2010; Bhang et al., 2011; Yan et al., 2011; Forcheron et al., 2012; Krumboeck et al., 2013; Yuan et al., 2013). As is the case in bone marrow derived MSCs, ADSCs are may undergo differentiation into a variety of distinct mature tissue types including fat, cartilage, bone, skin, muscle, endothelial, and nerve-like cells when grown with a particular set of induction factors (Zuk et al., 2001; Mizuno, 2009; Ebrahimian et al., 2009; Tremolada et al., 2010). ADSCs also boast the additional benefits that the stem cell yield from fat is 500 -fold greater than that obtained from bone marrow (Fraser et al., 2006) - $\left[5 \times 10^{5}\right.$ ADSCs can be derived from 400-600g of fat (Zhu Y et al., 2008; Marigo and Dazzi, 2011)]; and that ADSCs easier and less invasive to harvest overall (Ross et al., 2014; Shukla et al., 2015).

In terms of the cellular secretory profile, ADSCs produce a more extensive range of chemokines, cytokines and protein growth factors (Caplan AI, 2006; Dominici et al., 2006; Kilroy et al., 2007; Locke et al., 2009; Blaber et al., 2012; Carrade et al., 2012; Cawthorn et al., 2012; Hsiao et al., 2012; Strioga et al., 2012). This secretome profile has contributed the understanding that, in contrast to previously held theories that ADSCs would differentiate to actually replace damaged cells (the "building block" or "host replacement" theories (Neuhof and Hirshfeld, 1923; Yoshimura et al., 2006; Kim et al., 2009; Zuk, 2013; Ross et al., 2014); the paracrine effects of the secretome are now considered as more likely to orchestrate the events needed tissue regeneration (Phinney and Prockop, 2007). The distinct makeup of the ADSCs secretome suggested that ADSCs may influence tissue regeneration by altering the biological and molecular cues driving (Gronthos et al., 2001; Kim et al., 2009; Baer and Geiger, 2012; Collawn et al., 2012; Forcheron et al., 2012), angiogenesis (Bhang et al., 2011; Zimmerlin et al., 2011; Matsuda et al., 2013; Yuan et al., 2013) and lymphangiogenesis (Lin et al., 2010; Yan et al., 2011); while suppressing local immune/inflammatory responses (Fraser et al., 2006; Rigotti et al., 2007; Delay et al., 2009; Tremolada et al., 2010; Marigo and Dazzi, 2011; Cawthorn 
et al., 2012) and reducing fibrogenesis (Tremolada et al., 2010).

Since the time of the initial description of ADSCs, their molecular profile has been the subject of debate (Stone et al., 2003; Mazzola et al., 2011). This has been chiefly due to the description of different ADSC purification and culture protocols and differing use of sub-total vs. whole SVF (Coleman, 2001; Rigotti et al., 2007; Locke et al., 2009; Yoshimura K, 2010; Cawthorn et al., 2012; Strioga et al., 2012).

\section{Safety Concerns and Legislative Implementation of Fat Grafting in Clinical Practice}

Concerns regarding the use of ADSCs in clinical practice have been three-fold. Firstly, fears arose that introducing stem cells into a former cancer field might encourage recurrent cancer growth due to potential secretion of pro-angiongenic growth factors such as VEGF-A (Ross et al., 2014; Shukla et al., 2015). Secondly, it was hypothesized that chronic calcification occurring in the previously fat grafted areas may make screening/monitoring for the occurrence further cancer difficult (Ross et al., 2014; Shukla et al., 2015). Finally, the addition of components to enhance ADSC efficiency-such as collagenase processing-created the impression that the fat has been significantly altered and therefore ceases to be an autologous tissue transfer, but more a modified therapeutic product (Raposio and Ciliberti, 2017). The first of these reservations was addressed when it was contested that, despite in-vitro data that suggesting that introducing stem cells might promote cell proliferation, there was no equivalent definitive evidence in-vivo to that effect (Ross et al., 2014; Shukla et al., 2015; Simonacci et al., 2016). The second concern was deemed not to be an issue in the hands of an experienced radiologist, who should be expected to differentiate between benign "post-graft" and suspicious calcification (Ross et al., 2014; Shukla et al., 2015; Simonacci et al., 2016). A recommendation of the American Society of Plastic Surgeons against fat grafting for breast reconstruction was dropped in 2009, and subsequent case studies have upheld an acceptable risk profile. (Ross et al., 2014; Shukla et al., 2015; Simonacci et al., 2016). Finally, the addition of processing to fat graft to enhance take rates has rendered the fat graft unusable in some jurisdictions. In Europe, the use of collagenase digestion in fat grafting is considered to be a significant manipulation of the graft and therefore no longer to be homologous (Raposio and Ciliberti, 2017). The practical use of manipulative steps is therefore likely to remain a restricted procedure, and would likely need to pass regulatory approval steps akin to those stringent steps required of devices or genetically modified cell treatments.

\section{Functions of ADSCs in Tissue Regeneration}

Since the initial observations made in clinical fat grafting, adipogenic differentiation of ADSCs has been thought to result in restoration of tissue contour and volume. Clinical work indicates that there is new fat near the area of the fat graft introduction, which must have occurred via either; i) direct differentiation of introduced ADSC into adipocytes; or ii)
ADSCs exerting paracrine effects to influence local stem cells to differentiate into adipocytes (Zuk et al., 2001; Rigotti et al., 2007; Delay et al., 2009; Ebrahimian et al., 2009; Kim et al., 2009; Mizuno, 2009; Uysal et al., 2009; Eto et al., 2011; Mazzola et al., 2011; Karathanasis V et al., 2013). The latter has gained favor of late.

\section{Differentiation of Transplanted ADSC During Wound Healing}

There are several studies demonstrating that transplanted ADSC can potentially promote wound healing by differentiating into specific cell types in animal models of wound healing. For example, Nie et al. showed that intradermally administered ADSCs facilitated wound closure in rats by enhancing reepithelialization and granulation tissue deposition (Nie et al., 2011). The enhanced wound repair in these rats was attributed to differentiation of ADSC into epithelial and endothelial cells, which accelerated cutaneous regeneration and angiogenesis (Nie et al., 2011). Kim et al. assessed the efficacy of ADSCs in promoting wound healing introduced via three different techniques (topical application, intravenous injection and intramuscular injection) (Kim et al., 2019). This study found that mice treated with ADSC exhibited more stratified and differentiated epidermal and dermal layers, with more rapid reepithelialization and vascularization regardless of the type of ADSC administration compared to control mice (Kim et al., 2019). Further, Wu et al. employed an ADSC-seeded silk fibroin chitosan film in a rat incisional cutaneous wound healing model, and showed accelerated wound healing and colocalization of transplanted ADSCs which displayed enhanced levels of endothelial markers CD31 and alpha-smooth muscle actin ( $\alpha$ SMA) (Wu et al., 2018). These findings were consistent with another study using an acute radiation ulcer model in rats, in which a portion of transplanted ADSCs were also shown to be colocalized with CD31 (Huang et al., 2013). These findings suggest that these ADSCs may have partially differentiated into endothelial cells to promote angiogenesis during wound healing. Lastly, subcutaneously injected ADSCs resulted in a significant increased angiogenesis and enhanced wound healing at 8 weeks post-implantation in rats (Kuo et al., 2016). Unfortunately, however, these studies failed to directly address the question of whether ADSCs promoted wound healing by differentiating into specific cells types, such as epithelial or endothelial cells, or whether-as the authors claimed-that the increased angiogenesis was due to the ADSC secretomes, including VEGF-A (Kuo et al., 2016). A limitation of these studies was that they were conducted using tissue immunofluorescence, which relies on optical co-localization of markers that can be more misleading in terms of positive ADSC and CD31 signals, compared to PCR that will tease out distinct cell populations that co-express numerous specific markers. Finally, no differentiation of ADSCs was detected in a rabbit model of wound healing 7 days after topical application, although the animals treated with ADSCs did increase granular tissue formation in the wound area (Hong et al., 2013). This finding may suggest that the microenvironment in wounds between rodents and rabbits is 
critically different, or that ADSC differentiation may not play a significant role as the paracrine secretome of the ADSC population. Further research is required to better understand the differentiating capacity of transplanted ADSC in vivo.

\section{Non-Differentiation Related Mechanisms: Enhancement of Angiogenesis and Lymphangiogenesis \\ Angiogenesis}

Injection of the ADSCs into the recipient tissue bed is thought to increase perfusion of injured tissues and/or graft viability by: i) paracrine promotion of angiogenesis, or ii) supporting existing vascular structures. The concepts that support the existence of such regenerative mechanisms are based on several key findings regarding fat grafting in murine ischemic injury models (Eto et al., 2011). These experiments demonstrated that: i) ADSCs may differentiate into $\mathrm{CD} 31^{+}$ECs in-vivo; ii) there was enhance density of blood vessels and co-localized fluorescent-labeled ADSCs in or near the vessels; and iii) ADSCs formed a $\mathrm{vWF}^{+}$vessel networks in a Matrigel matrix (Karathanasis V et al., 2013). Further, the release of angiogenic growth factors by ADSCs has been shown to promote revascularization and wound healing. These included proteins such as IGF, PDGF-bb, FGF, TGF- $\beta$, and interleukins IL-6, IL-8, stromalrelated proteins MMP inhibitor 1 precursor, MCP-1, ANG, and SDF-1, and vascular-related proteins such as vascular endothelial growth factor (VEGF) -A, -C, and -D, (Rehman et al., 2004; Benvenuto et al., 2007; Kilroy et al., 2007; Kim et al., 2008; Lu et al., 2008; Ebrahimian et al., 2009; Mizuno, 2009; Pallua et al., 2009; Uysal et al., 2009; Marigo and Dazzi, 2011; Eto et al., 2011; Heo et al., 2011; Zografou et al., 2011; Baer and Geiger, 2012; Forcheron et al., 2012; Hsiao et al., 2012; Kapur and Katz, 2013; Haubner et al., 2013; Jiang et al., 2013; Karathanasis V et al., 2013; Yuan et al., 2013).

\section{Lymphangiogenesis}

ADSCs secrete lymphangiogenic factors that aid in lymphangiogenesis, improving or reversing lymphedema in damaged tissues. Lymphatic fluid stasis was found to result in increased TGF- $\beta 1$, exerting a hypothesized further antilymphangiogenic effect. Blockade of TGF- $\beta 1$ and ADSC stimulation, in contrast, lead to increased expression levels within ADSCs of lymphatic endothelial cell markers podoplanin and Prox-1 and of lymphangiogenic growth factor VEGF-C. In addition, the protein growth factors detected in ADSCs that differentiate them from other MSCs (VEGF-D, IGF1, and IL-8) at baseline, all display pro-lymphangiogenic activity (Ji, 2007; Rigotti et al., 2007; Delay et al., 2009; Avraham et al., 2010; Mazzola et al., 2011; Yan et al., 2011).

\section{Anti-Oxidant, Anti-Inflammatory and Anti-Fibrosis Effects}

ADSCs may elicit regenerative benefits by exerting anti-oxidant effects, which in turn provide protective effects combatting cellular injury induced by radical oxygen species, hypoxia, and reperfusion effects following ischemia. Protein growth factors that have been implicated include PDGF-AA, HGF, IL-12, GCSF, GM-CSF, IGFBPs. Pigmented epithelial derived growth factor, Superoxide dismutase may mediate these effects (Chen et al., 2008; Kim et al., 2008; Kim et al., 2009; Heo et al., 2011;
Chang et al., 2013). Specific ADSC-induced cytokines have also been shown to modulate immune and inflammatory responses, as BMSCs, and ADSCs restrict the proliferation T-cells and Bcells through NFKB-mediated pathways. Further, IL-6 and IL-8 secretion act as attractants for monocytes and macrophages, which also promote wound healing processes (Ohnishi et al., 2007; Chen et al., 2008; Goh et al., 2010; Heo et al., 2011; Marigo and Dazzi, 2011; Nambu et al., 2011; Forcheron et al., 2012; Rodriguez-Menocal et al., 2012; Kapur and Katz, 2013; Haubner et al., 2013; Jiang et al., 2013).

An additional method of improving epithelialization and wound healing has been shown to be through modulation of granulation tissue formation and of fibrosis. ADSCs co-cultured with fibroblasts in-vitro appeared to modify extracellular matrix (ECM) remodeling through down-regulation of gene expression related to production of collagen types I and types III by fibroblasts. Functionally, treatment of keratinocyte and fibroblasts with conditioned media (CM) harvested from ADSC (ADSC ${ }^{\mathrm{CM}}$ ) lead to improved re-epithelialization (Bensidhoum et al., 2005; Francois et al., 2007; Mouiseddine et al., 2007; Ohnishi et al., 2007; Greenberger and Epperly, 2009; Gimble et al., 2010; Goh et al., 2010; Lee et al., 2010; Heo et al., 2011; Nambu et al., 2011; Lee et al., 2012; Rodriguez-Menocal et al., 2012; Zhang et al., 2012; Chang et al., 2013).

Overall, the endogenous stem cell recruitment along a chemokine gradient to the site of injury or inflammation resulted in improved wound healing, truncation of prolonged inflammatory responses and tissue regeneration (Greenberger and Epperly, 2009). Murine models have demonstrated that MSCs respond by aggregating to a site of tissue damage. Studies tracking systemically introduced human MSCs showed that they home to and became grafted into the site of ischemia or of a necrotic injury. In these studies, SDF1 $\alpha$, produced by ADSCs was the key chemoattractant of other stem cells to the injured area of tissue (Bensidhoum et al., 2005; Francois et al., 2007; Mouiseddine et al., 2007; Dewhirst et al., 2008; Greenberger and Epperly, 2009; Gimble et al., 2010; Suga et al., 2010; Eto et al., 2012; Zhang et al., 2012; Chang et al., 2013; Frazier et al., 2013).

\section{Implications of Age-Related Changes to Fat Grafting in Clinical Practice}

Several clinical applications for adipose-derived stem cell therapy are related to diseases that become more prevalent with age. In studies that examined the changes to the stem cell population, it was found that the differentiation and other functional profiles changes between cells from infanthood, middle age, and elderly donors (Jin et al., 2017). Other studies also demonstrated reduced proliferation and migration profile with age, however, this effect was less marked in adipose-derived cells than it was in bone marrow derived stem cell populations (Efimenko et al., 2015). When stem cells were harvested from aged patients and mice, ADSCs were more robust in terms of potential cell yield than was the case with other MSCs, however, in terms of the paracrine signaling and angiogenic potential of stem cells (e.g., in terms of VEGF-A production), there was a marked impairment seen in cells taken from older donors in both in vivo and in vitro models (Efimenko et al., 2015). Similarly, clonogenic potential in 
ADSCs was reduced with age and all the effects were linked to a likely telomere shortening and accumulation of reactive oxygen species-related cellular injury (Efimenko et al., 2015). Overall, aging of donor stem cell populations may form an important limitation of the ability of ADSCs to delivery therapeutic benefits that can be derived from younger donor stem cell populations. This limitation may constitute an indication for ADSC function testing prior to clinical use, bolster the case for procedures to enhance ADSC efficacy, or herald the requirement for a delivery system that by-passes the ADSC itself to harness the paracrine secretome and cell products in a more targeted fashion-such as the use of exosomes.

\section{Alternative Approaches to Deliver Beneficial Effects of ADSCs: Small Extracellular Vesicles \\ Extracellular Vesicles: Understanding Their Composition}

Extracellular vesicles (EVs) are a heterogeneous population of nano- and micro-sized membrane-encapsulated cell particles that are fundamental mediators of intercellular communication. EVs constitute a diverse range of subtypes, namely microvesicles, exosomes, and several other EV populations, classified by The International Society for Extracellular Vesicles (ISEV) (Thery et al., 2018). All cell types continuously secrete EVs to the extracellular environment. EVs contain select proteins, peptides, RNA species (microRNAs, mRNAs, and long noncoding RNAs), lipids, and DNA fragments, that act locally or disseminate through circulation to act at specific distal sites to pleiotropically modulate cellular responses via paracrine signaling (Greening et al., 2016; Xu et al., 2018; Rai et al., 2019). The origin, nature, morphology, size and content of EVs are diverse and represent a novel signaling paradigm (Antonyak and Cerione, 2015). EV trafficking has been studied extensively in the area of oncology; however, there is now evidence of their seminal roles in intercellular communication in fetal-maternal signaling (Evans et al., 2019) and metabolism and tissue regeneration - particularly as trafficking intermediates for adipose tissue (Thomou et al., 2017). EVs may be divided into distinct classes, each with differing composition, capacity for selective packaging and potential for targeted delivery (and thus potential roles in disease). Comprehensive examination of the composition and molecular function of EVs in physiology and pathophysiology must be explored in the context of individual cell types, in order to facilitate cell-specific functions and therapeutic use [reviewed in (Greening and Simpson, 2018)].

\section{Defining Extracellular Vesicles}

Numerous terminologies have been described to define and identify EVs (Gould and Raposo, 2013). Overall, two main classes of EVs exist: large EVs (or shed microvesicles) and small EVs (or exosomes) (Colombo et al., 2014; van Niel et al., 2018). Large EVs $(\sim 150-1500 \mathrm{~nm})$ are generated by outward blebbing of specific regions of the plasma membrane (Tricarico et al., 2017; van Niel et al., 2018; Mathieu et al., 2019). Small EVs
(30-150 $\mathrm{nm}$ ) originate as intraluminal vesicles (ILVs) through the endosomal maturation pathway (i.e., multivesicular bodies (MVBs)), which can release ILVs as exosomes into the extracellular space (Raposo and Stoorvogel, 2013).

During their biogenesis, EVs are selectively enriched with diverse cellular bioactive cargo molecules. RNAs (coding, noncoding), DNAs (single-/double-stranded), proteins (peptides, fusion proteins), and lipids are selectively incorporated into distinct types of EVs (van Niel et al., 2018; Mathieu et al., 2019). Further, diverse surface-bound proteins (e.g., receptors, tetraspanins) that are characteristic of the cell of origin, are selectively displayed on secreted EVs and play a crucial role in the recognition of target recipient cells and orchestrating EV localization; as well as uptake by recipient cells (Xu R. et al.,2019).

Although a growing number of studies have investigated the roles of EVs in cell-cell communication, an understanding of specific mechanisms behind their biogenesis and the heterogeneity of EVs and their subtypes remains rudimentary (Greening and Simpson, 2018). The heterogeneity of small EVs and the identification of non-vesicular extracellular content has raised concerns as to the content and function of some exosomes (Jeppesen et al., 2019). Currently, the extent to which small EVs (and exosomes) differ from other EVs in terms of their biogenesis and functions remains ill-defined; and specific markers that distinguish large from small EVs are the subject of much research (Ji et al., 2014; Greening et al., 2017; Greening and Simpson, 2018; Thery et al., 2018; van Niel et al., 2018; Xu et al., 2018; Zhang et al., 2018; Claridge et al., 2019; Jeppesen et al., 2019). This research includes the characterization of EV classes and their subtypes, imaging and tracking of EVs, mechanisms of cell and tissue targeting and internalization, post-translational and transcriptional regulation of EVs and their cargo, and administration and duration (i.e., transient vs. stable) of functional effects (Xu et al., 2016; Greening and Simpson, 2018; van Niel et al., 2018; Xu et al., 2018; Mathieu et al., 2019).

\section{Isolating and Purifying Extracellular Vesicles for Biophysical Studies and Clinical Utility}

The majority of rapid/one-step approaches for isolating EVs do not account for the fact that samples may contain a mixture of vesicle classes/subtypes and co-isolated contaminants such as high-molecular weight protein oligomers, RNA granules, and protein-RNA complexes (e.g., high-/low-density lipoproteins, argonaute-2/AGO2) complexes (Jeppesen et al., 2019). Varying methodologies for purifying (enriching) EVs and their modified versions exist, including differential (sequential) ultracentrifugation, density-based fractionation, gel permeation chromatography, affinity chromatography using bio-specific reagents (e.g., antibody targets), membrane ultrafiltration using low-centrifugal force, microfluidic devices, and synthetic polymer based precipitation reagents [for a discussion on application, yield/purity and scalability of these methods, see (Xu et al., 2016; Li et al., 2017)]. The choice of which method for $\mathrm{EV}$ isolation used depends on the specific research question or proposed use, as outlined below. Further detail of specific 
guidelines as recommended by ISEV for studies of EVs has been reported elsewhere (Thery et al., 2018).

\section{Stringent EV Isolation Procedures}

EVs can be isolated and purified depending on the application. For stringent biochemical analysis [e.g. define their luminal cargoRNA/DNA/lipid/protein species and surface-exposed proteins (Xu R. et al., 2019)] or specific functionality, rigorous purification strategies are critical, including immunoaffinity targeting. Antibody targets that have been successfully employed in this process include those directed against A33 (Mathivanan et al., 2010), EpCAM (Yoo et al., 2012; Tauro et al., 2012), MHC-II antigens (Clayton et al., 2001; Keryer-Bibens et al., 2006), CD45 (Coren et al., 2008; Mercier et al., 2013), CD63 (Caby et al., 2005; Oksvold et al., 2014), CD81 (Oksvold et al., 2014), CD9/CD1b/ CD1a/CD14 (Wiley and Gummuluru, 2006), CD24/SWA11 (Rupp et al., 2011), and HER2 (Koga et al., 2005). Further, targeted EV capture based on bio-specific synthetic peptides (Ghosh et al., 2014) and proteoglycan enrichment (Christianson et al., 2013; Balaj et al., 2015) have been described. Other approaches to purify EVs include sequential centrifugal membrane ultrafiltration (Xu et al., 2015) and density-based fractionation using differential centrifugation (i.e., top- or bottom-loaded) (e.g., OptiPrep ${ }^{\mathrm{TM}} /$ iodixanol) (Ji et al., 2013; Carrasco-Ramirez et al., 2016; Greening et al., 2016; Willms et al., 2016).

\section{Generation of EVs for Therapeutic Studies}

By virtue of their bioactive cargo EVs have inherent therapeutic potential (Dean et al., 2013; De Toro et al., 2015; Reiner et al., 2017). Small EVs from human MSCs have been used in tissue regenerative medicine to reduce infarction size in a mouse model of myocardial ischemia/re-perfusion injury (Lai et al., 2015). For these studies, large-scale production of functional homogeneous MSC-derived exosomes was accomplished using size-based fractionation. In another therapeutic application, small EVs from dendritic cells (and tumor cells) have been trialed in vaccine studies (Romagnoli et al., 2014; Kunigelis and Graner, 2015; Pitt et al., 2016; Tian and Li, 2017). Navabi et al. described a large-scale production method combining ultrafiltration and sucrose/deuterium oxide for generating good manufacturing (GMP) grade small EVs for use in clinical trials (Navabi et al., 2005).

\section{Extracellular Vesicle Regulation of Adipose Function}

Several key studies have demonstrated the role of EVs in adipose function. Recently, adipose tissue macrophages were shown to release exosomes containing a specific miRNA to facilitate glucose intolerance (from fat mice population) and insulin resistance (in lean mice population) (Wu et al., 2017). Exosomecontaining miR-155 was shown to transfer into insulin target cell types, regulating cellular insulin response, insulin sensitivity, and glucose homeostasis (Wu et al., 2017). The ability of adipose tissue macrophage-derived exosomes to modulate systemic insulin and glucose tolerance via different miRNA compositions depended on their adipose phenotype (Wu et al., 2017). Thomou et al. further highlighted the contribution of adipose EVs to adipose function, with 653 miRNAs expressed in serum-derived exosomes from nonobese, or non-diabetic mice (Thomou et al., 2017). Importantly, adipocyte-specific Dicer KO mice were used to deplete adipocytederived miRNAs, revealing that exosomes from adipocytes containing miR-99b, inhibited liver FGF21 expression (Thomou et al., 2017). It was further suggested that these changes in FGF21 facilitated the overall phenotype of the Dicer KO mice. Interestingly, Ying et al. demonstrated that such changes were only marginally affected by adipose tissue macrophages-derived exosomes ( $\mathrm{Wu}$ et al., 2017), indicating that significant differences are present between the miRNA profiles of different cell types within the source adipose tissue. Finally, it was observed that in adipocytespecific Dicer KO, there was a substantial reduction in circulating exosomal microRNAs (Thomou et al., 2017).

A seminal study by Flaherty et al. identified that adipocytes communicate with adipose tissue macrophages through EVs (Flaherty et al., 2019). This is achieved by directly transferring lipids to differentiate bone marrow precursors into adipose tissue macrophage-like cells, with critical implications for obesityassociated pathologies (Flaherty et al., 2019). The authors highlighted the fact that adipose tissue from lean mice releases $\sim 1 \%$ of its lipid content per day via exosomes ex-vivo, a rate that more than doubles in obese animals. Amose et al. also showed that EVs in human plasma increased significantly with BMI, supporting a role of EVs as metabolic relays in obesity (Amosse et al., 2018). This study demonstrated a key role for large EVs in the transfer of macrophage migration inhibitory factor (MIF) and the link between adipose-derived EVs and macrophage regulation.

Further investigating the role of exosomes in adipose tissue, Crewe et al. showed that adipose tissue EVs modulated crosstalk between adipocytes and stromal vascular cells for metabolic signaling and regulation (Crewe et al., 2018). Quantities of adipose tissue EVs were increased in a fasted state (compared with genetic and diet-induced obesity), partially because of glucagon-stimulated EV secretion from endothelial cells (Crewe et al., 2018). The authors showed dysregulation of important signaling proteins (antioxidant response, mitochondrial respiration) and lipid species involved in stress response. A critical finding was that extracellular molecules are internalized and packaged into EVs (Crewe et al., 2018), representing a new mechanism by which blood-borne signals are integrated into and supplied to adipose tissues.

In addition to influencing fat biology, components of the ADSC secretome have also been shown to promote wound healing and neuro-regeneration, making it an exciting focus for discovery of potential therapeutic targets (Hu et al., 2016; Yim N et al., 2016); particularly as engineering-specific EV delivery systems is now a reality (Yim $\mathrm{N}$ et al., 2016).

\section{ADSCs for Therapeutic Application in Human Disease}

Pre-clinical studies of ADSCs and ADSC-exosomes/EVs are listed in Table 1 and Table 2, respectively. As the exosome/EV field is far less advanced than the clinical practice of fat grafting, the respective advances in the clinical application of each are considered together. 
TABLE 1 | Pre-clinical studies of ADSCs.

\begin{tabular}{|c|c|c|c|c|}
\hline $\begin{array}{l}\text { Disease } \\
\text { model }\end{array}$ & $\begin{array}{l}\text { In vitro or } \\
\text { In vivo }\end{array}$ & Function & Key findings with ADSC-CM & Reference \\
\hline $\begin{array}{l}\text { Cutaneous } \\
\text { wound }\end{array}$ & $\begin{array}{l}\text { In vitro } \\
\text { and in } \\
\text { vivo }\end{array}$ & Wound healing & $\begin{array}{l}\text { Reduced UVB-induced wrinkles in mice. Also, ADSC-CM (conditioned media) inhibited UVB-induced } \\
\text { apoptosis and enhanced type I collagen synthesis of human dermal fibroblasts }\end{array}$ & $\begin{array}{l}\text { (Kim et al., } \\
\text { 2009) }\end{array}$ \\
\hline $\begin{array}{l}\text { Cutaneous } \\
\text { wound }\end{array}$ & In vitro & Wound healing & Accelerated collagen deposits in human dermis through up-regulation of fibroblasts TGF- $\beta 1$ & $\begin{array}{l}\text { (Jung et al., } \\
\text { 2011) }\end{array}$ \\
\hline $\begin{array}{l}\text { Cutaneous } \\
\text { wound }\end{array}$ & In vivo & Wound healing & Promote neovascularization and wound repair by up-regulating Tgfb-1, Fgfb, \& Vegf gene expression & $\begin{array}{l}\text { (Hamada } \\
\text { et al., 2019) }\end{array}$ \\
\hline $\begin{array}{l}\text { Cutaneous } \\
\text { wound }\end{array}$ & $\begin{array}{l}\text { In vitro } \\
\text { and in } \\
\text { vivo }\end{array}$ & Wound healing & $\begin{array}{l}\text { Enhanced neovascularization and re-epithelialization of wounds by up-regulating VEGF, HGF an FGF } \\
\text { protein expression }\end{array}$ & $\begin{array}{l}\text { (Nie et al., } \\
\text { 2011) }\end{array}$ \\
\hline $\begin{array}{l}\text { Cutaneous } \\
\text { wound }\end{array}$ & In vivo & Wound healing & $\begin{array}{l}\text { ADSC + platelet-rich plasma activated Rho GTPase signaling and lead to accelerated wound cell } \\
\text { migration \& re-epithelialization }\end{array}$ & $\begin{array}{l}\text { (Zhang } \\
\text { et al., 2019) }\end{array}$ \\
\hline $\begin{array}{l}\text { Secondary } \\
\text { lymphedema }\end{array}$ & In vivo & Reduce tail swelling & Promote VEGF-C-mediated lymphangiogenesis and anti-inflammatory M2 macrophages recruitment & $\begin{array}{l}\text { (Shimizu } \\
\text { et al., 2012) }\end{array}$ \\
\hline $\begin{array}{l}\text { Radiation } \\
\text { injury }\end{array}$ & In vitro & Lymph-angiogenesis & Promoted bFGF-mediated lymphangiogenesis in irradiated LECs & $\begin{array}{l}\text { (Saijo et al., } \\
\text { 2019) }\end{array}$ \\
\hline $\begin{array}{l}\text { Alzheimer's } \\
\text { disease }\end{array}$ & In vivo & Neurogenesis & Secreted IL-10 and VEGF to reduce $A \beta$ plaques and promote neurogenesis and cognitive functions & (Kim et al., \\
\hline $\begin{array}{l}\text { Alzheimer's } \\
\text { disease }\end{array}$ & In vivo & Neurogenesis & Reduce oxidative stress and stimulate neuroblast proliferation to improve cognitive function & $\begin{array}{l}\text { (Yan et al., } \\
\text { 2014) }\end{array}$ \\
\hline $\begin{array}{l}\text { Parkinson's } \\
\text { disease }\end{array}$ & In vivo & Neuroprotection & $\begin{array}{l}\text { Inhibit dopaminergic neuronal cell death and reduce brain mitochondrial damage, restore } \\
\text { mitochondrial function }\end{array}$ & (Choi et al., \\
\hline $\begin{array}{l}\text { Parkinson's } \\
\text { disease }\end{array}$ & In vivo & Neuroprotection & Improved motor function by increasing BDNF and GFPA & (Berg et al., \\
\hline $\begin{array}{l}\text { Huntington's } \\
\text { disease }\end{array}$ & In vivo & Neuroprotection & $\begin{array}{l}\text { ADSC-extracts improve rotarod test and reduce } \mathrm{mHtt} \text { aggregates and striatal atrophy via CREB- } \\
\text { PGC1 } \alpha\end{array}$ & (Im et al., \\
\hline $\begin{array}{l}\text { Huntington's } \\
\text { disease }\end{array}$ & In vivo & Neuroprotection & $\begin{array}{l}\text { Improved rotarod performance and limb clasping, increased survival, protected striatal neurons and } \\
\text { decreased } \mathrm{mHtt} \text { aggregates }\end{array}$ & $\begin{array}{l}\text { (Lee et al., } \\
\text { 2009) }\end{array}$ \\
\hline $\begin{array}{l}\text { Acute kidney } \\
\text { injury }\end{array}$ & In vivo & Renal protection & $\begin{array}{l}\text { Attenuate I/R-induced renal damage by suppressing apoptosis and inflammation via reduction in levels } \\
\text { of pro-apoptotic and pro-inflammatory cytokines }\end{array}$ & $\begin{array}{l}\text { (Zhang } \\
\text { et al., 2017) }\end{array}$ \\
\hline $\begin{array}{l}\text { Diabetic } \\
\text { nephropathy }\end{array}$ & In vivo & Renal protection & Reduce oxidative stress and inflammation by inhibiting p38 MAPK signaling pathway & $\begin{array}{l}\text { (Fang et al., } \\
\text { 2012) }\end{array}$ \\
\hline $\begin{array}{l}\text { Breast } \\
\text { cancer }\end{array}$ & In vivo & $\begin{array}{l}\text { Tumor promotor or } \\
\text { tumor suppressor }\end{array}$ & $\begin{array}{l}\text { ADSC injected into tumor promote tumor growth, c.f. ADSC injected around tumor inhibits tumor } \\
\text { growth }\end{array}$ & (Illouz, \\
\hline $\begin{array}{l}\text { Breast } \\
\text { cancer }\end{array}$ & In vivo & Tumor promotor & Promoted pulmonary metastases by inhibiting miR-20b \& activating c-Kit/MAPK-p38/E2F1 signaling & $\begin{array}{l}\text { (Xu H. } \\
\text { et al., 2019) }\end{array}$ \\
\hline
\end{tabular}

\section{Wound Healing}

A wound consists of an area of disrupted tissue integrity, architecture and homeostasis. It may be caused by trauma or by thermal or radiation injury (Devalia and Mansfield, 2008; Fry, 2017). The process of wound healing involves a series of organized molecular events including inflammation, neo-vascularization, scar tissue formation, and tissue remodeling (Gurtner et al., 2008); processes tightly regulated by specific growth factors, such as TGF- $\beta$, FGF, and PDGF (Grazul-Bilska et al., 2003). In most injuries, wound repair results in scar formation due to recruitment of collagen secreting fibroblasts to enhance the deposition of collagenous ECM (Gurtner et al., 2008). The beneficial effects of $A D S C^{C M}$ on wound healing have been reported in several pre-clinical studies. For example, reduced proliferative capacity and increased apoptosis seen in UVB-irradiated human dermal fibroblasts were reversed with $\mathrm{ADSC}^{\mathrm{CM}}$ treatment (Kim et al., 2009). Similarly, it was shown that ADSC ${ }^{\mathrm{CM}}$ stimulated synthesis of type I collagen by human dermal fibroblasts and reduced UVB-induced wrinkles in mice (Kim et al., 2009). Another study demonstrated that the mRNA expression of types I and III collagens were enhanced in human dermal fibroblasts following treatment with $\operatorname{ADSC}^{\mathrm{CM}}$ (Jung et al., 2011).
In addition, animal models have shown promising effects of ADSCs on accelerating wound repair. For example, treatment using artificial dermis as a supportive matrix impregnated with autogenic ADSCs in wounded rats resulted in increased vascularization and healing, which was mediated by increased gene expression of genes involved in tissue repair or angiogenesis [e.g., Tgfb-1 and -3, Fgfb and Vegf (Hamada et al., 2019)]. Also in rats, Nie et al. employed an excisional wound healing model and demonstrated that ADSCs secreted pro-angiogenic mediators both in vitro and in vivo (e.g., VEGF-A, HGF, and FGF), in-turn promoting neo-vascularization and re-epithelial regeneration of wounds, thus accelerating the wound repair (Nie et al., 2011). Further, the wound healing effects of ADSCs in skin seems to be augmented when administered in combination with platelet-rich plasma containing several different protein growth factors and cytokines, including FGF, TGF- $\beta$ and PDGF (Zhang et al., 2019). The study suggested enhanced wound closure in treated mice via activation of the Rho GTPase signaling pathway, which is involved in cell migration and invasion (Lawson and Ridley, 2018). Collectively, these findings suggest that ADSCs are a potential therapeutic tool for promoting wound healing. 
TABLE 2 | Pre-clincial studies of ADSC-EVs.

\begin{tabular}{|c|c|c|c|c|}
\hline Disease model & $\begin{array}{l}\text { In vitro or } \\
\text { In vivo }\end{array}$ & Function & Key findings & Reference \\
\hline Myocardial I/R injury & In vivo & $\begin{array}{l}\text { Cardio- } \\
\text { protection }\end{array}$ & Reduced oxidative stress-induced necrosis and apoptosis in myocardium & $\begin{array}{l}\text { (Cui et al., } \\
\text { 2017) }\end{array}$ \\
\hline Acute myocardial infarction & In vivo & $\begin{array}{l}\text { Cardio- } \\
\text { protection }\end{array}$ & $\begin{array}{l}\text { Reduced cardiac apoptosis, fibrosis \& inflammation via S1P/SK1/S1PR1 pathway \& } \\
\text { macrophage M2 polarization }\end{array}$ & $\begin{array}{l}\text { (Deng et al., } \\
\text { 2019) }\end{array}$ \\
\hline Acute myocardial infarction & In vivo & $\begin{array}{l}\text { Cardio- } \\
\text { protection }\end{array}$ & $\begin{array}{l}\text { miR-126-enriched ADSC-exosomes reduced cardiac inflammation \& fibrosis, induce } \\
\text { microvascular generation \& migration }\end{array}$ & $\begin{array}{l}\text { (Luo et al., } \\
\text { 2017) }\end{array}$ \\
\hline Stroke & In vivo & $\begin{array}{l}\text { Neuro- } \\
\text { protection }\end{array}$ & $\begin{array}{l}\text { miR-126-enriched ADSC-exosomes induced neurogenesis, vasculogenesis \& inhibit post- } \\
\text { stroke inflammation }\end{array}$ & $\begin{array}{l}\text { (Geng et al., } \\
\text { 2019) }\end{array}$ \\
\hline Stroke & In vivo & $\begin{array}{l}\text { Neuro- } \\
\text { protection }\end{array}$ & $\begin{array}{l}\text { miR-181-b-5p-enriched ADSC-exosomes promote angiogenesis of brain microvascular } \\
\text { ECs post } \mathrm{O}_{2} \text {-glucose deprivation }\end{array}$ & $\begin{array}{l}\text { (Yang et al., } \\
\text { 2018) }\end{array}$ \\
\hline Neural injury & In vivo & $\begin{array}{l}\text { Neuro- } \\
\text { protection }\end{array}$ & $\begin{array}{l}\text { Reduced neuro-inflammation by suppressing microglia cells activation by inhibiting NF- } \kappa \beta \\
\text { and MAPK pathways }\end{array}$ & $\begin{array}{l}\text { (Feng et al., } \\
\text { 2019) }\end{array}$ \\
\hline Neural injury & In vivo & $\begin{array}{l}\text { Neuro- } \\
\text { regeneration }\end{array}$ & $\begin{array}{l}\text { Promote axonal regeneration \& myelination in atrophied gastrocnemius by stimulating } \\
\text { secretion of neurotrophic factors from Schwann cells }\end{array}$ & $\begin{array}{l}\text { (Chen et al., } \\
\text { 2019) }\end{array}$ \\
\hline Alzheimer's disease & In vitro & $\begin{array}{l}\text { Neuro- } \\
\text { protection }\end{array}$ & Inhibit formation of $A \beta$ plaques and induce neuronal cells proliferation & $\begin{array}{l}\text { (Lee et al., } \\
\text { 2018) }\end{array}$ \\
\hline Huntington's disease & In vitro & $\begin{array}{l}\text { Neuro- } \\
\text { protection }\end{array}$ & $\begin{array}{l}\text { Reduce mutant Huntingtin protein aggregates, ameliorated abnormal apoptotic protein } \\
\text { levels, \& restored mitochondrial function }\end{array}$ & $\begin{array}{l}\text { (Lee et al., } \\
\text { 2016) }\end{array}$ \\
\hline Parkinson's disease & In vivo & $\begin{array}{l}\text { Neuro- } \\
\text { protection }\end{array}$ & $\begin{array}{l}\text { Reduce gene expression of GFAP, restore astrocytic injury, and increasing dopamine } \\
\text { levels }\end{array}$ & $\begin{array}{l}\text { (Meligy et al., } \\
\text { 2019) }\end{array}$ \\
\hline $\begin{array}{l}\text { Acute kidney injury and } \\
\text { chronic kidney disease }\end{array}$ & In vivo & $\begin{array}{l}\text { Renal } \\
\text { protection }\end{array}$ & Promoted tubular regeneration and inhibit AKI-CKD transition via SOX9 activation & $\begin{array}{l}\text { (Zhu et al., } \\
\text { 2017) }\end{array}$ \\
\hline Acute kidney injury & In vivo & $\begin{array}{l}\text { Renal } \\
\text { protection }\end{array}$ & $\begin{array}{l}\text { Combined ADSC + ADSC-exosomes reduce renal inflammation, oxidative stress, } \\
\text { apoptosis, fibrosis, \& glomerular \& tubular damage }\end{array}$ & $\begin{array}{l}\text { (Lin et al., } \\
\text { 2016) }\end{array}$ \\
\hline Diabetic nephropathy & In vivo & $\begin{array}{l}\text { Renal } \\
\text { protection }\end{array}$ & $\begin{array}{l}\text { Inhibit podocyte apoptosis and induced podocyte autophagy through miR-486-mediated } \\
\text { inhibition of Smad1/mTOR signaling pathway }\end{array}$ & $\begin{array}{l}\text { (Jin et al., } \\
\text { 2019) }\end{array}$ \\
\hline Breast cancer & In vitro & $\begin{array}{l}\text { Tumor } \\
\text { promotor }\end{array}$ & $\begin{array}{l}\text { Promote migration/proliferation of MCF7 human breast cancer cells via Wnt/ } \beta \text {-catenin } \\
\text { signaling pathway }\end{array}$ & $\begin{array}{l}(\text { Lin et al., } \\
\text { 2013) }\end{array}$ \\
\hline Prostate cancer & $\begin{array}{l}\text { In vitro \& } \\
\text { in vivo }\end{array}$ & $\begin{array}{l}\text { Tumor } \\
\text { suppressor }\end{array}$ & Inhibit tumor growth by activating caspase-3/7 pro-apoptotic miR-145 pathway & $\begin{array}{l}\text { (Takahara } \\
\text { et al., 2016) }\end{array}$ \\
\hline $\mathrm{HCC}$ & In vivo & $\begin{array}{l}\text { Tumor } \\
\text { suppressor }\end{array}$ & $\begin{array}{l}\text { miR-122 enriched ADSC-exosomes increase HCC chemosensitivity \& inhibit tumor } \\
\text { growth }\end{array}$ & $\begin{array}{l}\text { (Lou et al., } \\
\text { 2015) }\end{array}$ \\
\hline Breast cancer & In vivo & $\begin{array}{l}\text { Tumor } \\
\text { suppressor }\end{array}$ & miR-379 enriched ADSC-exosomes inhibited tumor growth over 6 weeks & $\begin{array}{l}\text { (O’Brien et al., } \\
\text { 2018) }\end{array}$ \\
\hline
\end{tabular}

\section{Extracellular Vesicles in Wound Healing}

Geiger et al. investigated the application of human fibrocytederived exosomes in diabetic mice. They found that wound healing was significantly enhanced in all parameters studied (Geiger et al., 2015). Zhang et al. found human umbilical cord MSC-derived EVs to promote re-epithelialization of a wound model and improved the Wnt 4 expression profile (Zhang et al., 2015). Similarly, Zhang et al. suggested that MSC-derived exosomes promote collagen formation and angiogenesis (Zhang et al., 2015). ADSC-derived exosome treatment of human dermal fibroblasts seemed to also induce enrichment of the microRNA within the fibroblasts that contribute to healing (Choi et al., 2018). In a murine wound model, Wang et al. suggested that IV administration of ADSC-exosome resulted in reduced scar size and altered metalloproteinases that may improve healing (Wang et al., 2017). Finally, Ren et al. showed that MVs from ADSCs stimulated proliferation and migration of fibroblasts, keratinocytes, and endothelial cells, particularly via the AKT and ERK signaling pathways both in vitro and in vivo (Ren et al., 2019).

\section{Radiotherapy Soft Tissue Injury}

Radiotherapy (RTX) is administered as part of cancer treatment, either before or after surgery or, unusually, in the absence of surgery (Ross et al., 2014; Shukla et al., 2015). The resulting injury may have devastating consequence in terms of chronic tissue fibrosis and breakdown that may expose vital underlying structures; or can cause secondary pain, contracture and functional impairment. ADSCs have been shown to enhance the quality of skin and soft tissues in clinical RTX injury and in animal models. These influences are thought to be mediated in a paracrine fashion by ADSC-secreted elements that counter the chemokine environment generated by the RTX-injury; this includes anti-inflammatory and anti-apoptotic effects (Ross et al., 2014; Shukla et al., 2015).

Haubner et al. investigated the influences of RTX in blood ECs, and showed enhanced gene expression of pro-inflammatory cytokines IL6, FGF, ICAM-1, and VCAM1. This model of coculture with ADSCs showed restoration of expression profiles of all RTX-altered cytokines (Haubner et al., 2013). Chang et al. also utilized intra-peritoneal ADSCs after local RTX to show abrogation 
of inflammation in treatment groups, with restored gastrointestinal tract (GIT) regeneration and enhanced survival (Chang et al., 2013). ADSC treatment was also linked with increased serum levels of IL10, VEGFA, bFGF, and EGF; in addition to increased SDF-1mediated stem cells recruitment to the injured area (Chang et al., 2013). Further, Kojima et al. and Lim et al. showed protective influences of ADSC against RTX-induced salivary gland irradiation (Kojima et al., 2011; Huang et al., 2013).

In terms of skin and subcutaneous RTX-induced damage, ADSC treatment resulted in improvement in mouse models of chronic RTX-related impaired wound healing and in unwounded RTX-damaged skin [marked by altered collagenbased scar index measurements, increased dermal thickening and reduced fibrosis marker Smad-3 (Sultan et al., 2011; Huang et al., 2013)]. A similar study, investigating ADSC-enriched fat grafting in larger animals exposed to RTX, showed labeled ADSC integration into skin and concomitant enhanced wound repair, epithelialization, subcutaneous fat reserves and lower apoptotic rates. In addition, recruitment and activation of lymphoid cells was seen (Forcheron et al., 2012; Chen et al., 2014).

\section{Lymphoedema}

Lymphoedema is the chronic swelling of a limb caused by an accumulation of excess interstitial fluid. In time, if unresolved, the fluid accumulation may lead to the formation of excess subcutaneous fibro-adipose tissue (Brorson, 2003). This condition most commonly occurs in a limb and may be the result a developmental malformation that leads to poor interstitial fluid drainage via the lymphatic system (primary lymphoedema) (Lee and Villavicencio, 2010). Alternatively, as is the case in most patients, lymphoedema may develop subsequent to a trauma to the lymphatic system. Typically, secondary lymphoedema occurs following surgery or RTX for cancer (in the developed world) or due to filarial infection (in the developing world) that damage lymphatic vessels and impair lymphatic drainage. The pathological features of secondary lymphoedema include inflammation, adipogenesis, and fibrosis.

Shimizu et al. demonstrated the therapeutic potential of ADSCs in lymphangiogenesis by implanting ADSCs into a surgical mouse model of secondary lymphoedema. They showed that ADSCs stimulated lymphangiogenesis by secreting VEGF-C, and enhanced the recruitment of anti-inflammatory M2 macrophages, which were associated with significantly reduced tail swelling in the model (Shimizu et al., 2012). A recent study by Saijo et al. suggested FGF as a novel factor in the ADSC secretome that could potentially contribute to lymphangiogenesis in irradiated human dermal lymphatic endothelial cells (LEC), implying that ADSCs may ameliorate RTX-injury in LECs (Saijo et al., 2019). Counter to this, however, early lymphangiogenesis has been highlighted as a possible risk factor associated with developing the later stages of lymphoedema in a surgical mouse model of secondary lymphoedema; and, paradoxically, pharmacological inhibition of lymphangiogenesis suppressed lymphedema development in the model (Ogata et al., 2016). Thus, whether ADSC-mediated lymphangiogenesis could be therapeutically beneficial in lymphoedema remains elusive and requires further investigation.
Mechanistic and small EV-based functional studies by Greening et al. linked key components of cancer cell-derived EVs to the modulation lymphatic vessel formation and metastasis, demonstrating that lymphatics can also be responsive to secretome components (Carrasco-Ramirez et al., 2016). This study demonstrated critical functional effects on lymphangiogenesis mediated by vesicle surface podoplanin (hitherto considered a passive marker of lymphatic endothelial tissue) on small EVs, using a specific neutralizing monoclonal surface-specific antibody. It also highlighted a key role of podoplanin in biogenesis and release of EVs, and in lymphangiogenesis function. However, the role of the ADSC secretome as a driver of lymphatic repair after RTX or other lymphatic injury, remains to be revealed.

\section{Neurodegenerative Diseases}

\section{ADSCs in the Treatment of Neurodegenerative Diseases}

The use of ADSCs has shown promising pre-clinical results in studies investigating several important neurodegenerative disorders, such as Parkinson's disease, Alzheimer's disease, and Huntington's disease. A study using a murine Alzheimer's disease model showed that treatment with human ADSCs significantly enhanced levels of the anti-inflammatory cytokine IL-10, as well as key neurotrophic (and vasculogenic) factors, including VEGF-A which led to a marked reduction in $\mathrm{A} \beta$ plaques and memory impairment, and elevation of endogenous neurogenesis and dendritic stability (Kim et al., 2012). Furthermore, autologous implantation of mouse ADSCs in mice with Alzheimer's disease enhanced regeneration of neuroblasts and reduced oxidative stress in the brain, which in turn alleviated cognitive impairment (Yan et al., 2014). Exosomes from ADSCs have also been shown to transfer enzymatically active neprilysin, a A $\beta$-degrading enzyme, in vitro (Katsuda et al., 2013). Importantly, this study showed that ADSC exosome-mediated function was more significant than bone marrow derived MSCs, contributing to prevention of extracellular plaque formation, subsequent pathogenesis and a potential Alzheimer's disease therapeutic.

In terms of Parkinson's disease, a common chronic progressive neurodegenerative movement disorder characterized in patients as diminished brain dopamine levels, numerous studies have been performed assessing the therapeutic potential of human ADSCs on a 6-hydroxyldopamine (6OHDA)-induced mouse Parkinson's disease model (Berman and Hastings, 1999). Mitochondrial dysfunction in the brain is known to contribute to pathogenesis of the disease by increasing reactive oxygen species and hence oxidative stress, which exacerbates damage to the dopaminergic neurons in Parkinson's disease (Berman and Hastings, 1999). Choi et al. demonstrated that ADSCs significantly improved behavioral performance by decreasing dopaminergic neuronal cell death and the population of damaged mitochondria in the mouse brain; as well as by recovering mitochondrial functions in the brains of ADSC-injected mice (Choi et al., 2015). It has also been shown that human ADSCs significantly enhanced expression of brain-derived neurotrophic factor (BDNF) and improved motor lost function in the 6-OHDA murine Parkinson's disease model (Berg et al., 2015), suggesting a pro-healing effect. Interestingly, 
however, the levels of glial fibrillary acidic protein (GFAP), were shown to be up-regulated in the brain of ADSC-treated animals (Berg et al., 2015). GFAP is a common indicator of dysfunctional astrocytes, the most abundant central nervous system glial cells. They may contribute to the progression of Parkinson's disease and GFAP upregulation is a possible sign of neuronal regeneration, however, it should be noted that a definitive role for GFAP is not yet agreed upon (Berg et al., 2015).

Huntington's disease is a progressive, fatal hereditary neurodegenerative disorder characterized by accumulated mutant Huntingtin (mHtt) protein in neural cells, which affects mitochondrial energy metabolism to accelerate cell death by progressive brain atrophy. Therefore, altered mitochondrial energy metabolism due to an impaired CREB-PGC1 $\alpha$ pathway is a key risk factor in disease progression, which is characterized by an accumulation of $\mathrm{mHtt}$ in the brain (Cui et al., 2006; Chaturvedi et al., 2010). Im et al. investigated the influences of cell-free extracts of human ADSC (ASC-E) on R6/2 mice, which developed Huntington's disease, and found that ASC-E induced activation of the p-CREP-PGC1 $\alpha$ pathway and amelioration of $\mathrm{mHtt}$ aggregates as well as striatal atrophy in the brain of R6/2 mice (Im et al., 2013). Also, injection of ASC-E in the mouse model slowed progression of the Huntington's disease phenotype, including weight loss and declining rotarod performance; although the molecular contents of the ASC-E that exerted these therapeutic effects was not assessed in this study (Im et al., 2013). Similarly, ADSC implantation in the R6/2 murine Huntington's disease model also showed beneficial effects, such as enhanced rotarod performance, limb clasp and survival; and attenuation of striatal neurons loss; as well as diminished brain aggregation of $\mathrm{mHtt}$ (Lee et al., 2009). These results were found to be driven by CREB-PGC1 $\alpha$ pathway activation (Lee et al., 2009). Altogether, these studies suggest that ADSC treatment could constitute a novel treatment tool useful in ameliorating key pathogenic steps in the development of Huntington's and other similar neurodegenerative diseases.

\section{Exosomes in the Treatment of Neurological Diseases}

There have been a few studies demonstrating critical roles of ADSC-exosomes in neuro-protection and neuro-regeneration owing to their capacity to cross the blood-brain barrier (Alvarez-Erviti et al., 2011). For instance, ADSC-exosomes have been shown to mediate functional neuro-regeneration in stroke. Geng et al. demonstrated in a rodent model that miR-126 enriched ADSC-exosomes enhanced neurogenesis and vasculogenesis after stroke (Geng et al., 2019). These results are in keeping with a rat experiment undertaken by Yang and colleagues, in which miR-181b-5p-enriched ADSC-exosomes promoted mobility and angiogenesis of brain microvascular endothelial cells in stroke (Yang et al., 2018). The manner in which exosomes transverse the blood-brain barrier by using transcytosis through endothelial cells are capable of mediating astrocytes to degrade the cell cytoskeleton (Morad et al., 2019), and have only recently been elucidated. Furthermore, neuroinflammation is a major complication of brain injury, which is triggered by the activation of microglia cells in the central nervous system (Dheen et al., 2007). miR-126-enriched ADSC-exosomes were shown to significantly inhibit post-stroke inflammation by suppressing activation of microglial cells and reducing pro-inflammatory cytokine levels in the rat brain (Geng et al., 2019). Feng et al. also demonstrated ADSC-exosomes to inhibit microglial activation by inhibiting the pro-inflammatory MAPK and NF- $\kappa \beta$ signaling pathways, which protected rat brain neural cells from injury (Feng et al., 2019).

Potential gene candidates in ADSC-exosomes that underpin these therapeutic effects have been explored using models of neurite outgrowth and sciatic nerve regeneration. Bucan et al. showed rat ADSC-exosomes to contain a range of neurotrophic factors, such as glial-cell derived neurotrophic factor, FGF-1, BDNF, ILGF-1, as well as nerve growth factor (NGF) (Bucan et al., 2019). Schwann cells are also simulated by neurotrophic factors NGF and BDNF and elicited pro-regenerative effects in nerve regeneration after nerve damage (Jessen and Mirsky, 2019). Chen et al. also demonstrated that exosomes derived from human ADSCs enhanced secretion of BDNF and NGF by Schwann cells, which led to increased proliferation, myelination, migration of cells in a dose-dependent manner in vitro (Chen et al., 2019). Additionally, this study assessed the effects of ADSC-exosomes on gastrocnemius muscle atrophy (a readout of sciatic nerve injury in rats) and found that treatment with the ADSC-exosome improved muscle atrophy by promoting axonal regeneration and myelination; although exosomal components that exerted these effects remained unidentified (Chen et al., 2019). Lastly, another study showed ADSC-exosomes to inhibit apoptosis and increase proliferation of Schwann cells in rats after nerve injury (Chen et al., 2019); an additional potential mechanism by which the ADSC-exosomes may promote nerve regeneration.

Several other studies demonstrated beneficial effects of ADSC-exosomes on key neurodegenerative diseases. Lee et al. demonstrated that ADSC-EVs significantly reduced the levels of $\mathrm{A} \beta$ plaques in Alzheimer's disease, inhibiting apoptosis of neuronal cells and augmenting neurite outgrowth of neuronal cells in vitro (Lee et al., 2018). In Huntington's disease (Cho et al., 2019), Lee el al. showed that Huntington's disease model that ADSC-EVs profoundly decreased mHtt aggregates and inhibited apoptosis of neuronal cells in vitro. Mitochondrial dysfunction was attenuated by activation of the proliferator-activated receptor $\gamma$ coactivator $1 \alpha(\mathrm{PGC} 1 \alpha)$ and $\mathrm{cAMB}$ response element binding protein (CREB)-peroxisome pathways (Cui et al., 2006; Chaturvedi et al., 2010; Lee et al., 2016). Finally, in Parkinson's disease (McGregor and Nelson, 2019). Meligy et al. studied a rotenone-induced rat model of Parkinson's disease to demonstrate that ADSC-EVs significantly increased levels dopamine in the treatment group compared to the control (Meligy et al., 2019). In contrast to the overexpression of GFAP seen in animals treated with ADSCs (Clairembault et al., 2014), it was shown that ADSC-EVs markedly decreased the gene expression of GFAP, restored astrocytic injury, and improved motor performance in their Parkinson's disease model (Meligy et al., 2019). This suggested that GFAP may play a different role in neuroprotection in the same model whether treated with 
ADSCs or ADSC-EVs. Overall, these results indicated that the ADSC-EVs may have reparative potential in incurable neurodegenerative disorders. Further studies are needed to understand the neuroprotective mechanisms by EVs.

\section{ADSCs in Renal Diseases}

$\mathrm{AKI}$ is a complex clinical condition characterized by deteriorating renal function due to decreased renal perfusion, blood supply and glomerular filtration rates, caused by damage to nephron structures (Prowle et al., 2010; Ostermann and Joannidis, 2016). AKI may progress to long-term chronic kidney disease (CKD), for which there is currently no cure (Rafieian-Kopaei, 2013). Thus, prevention of transition of AKI to CKD is critical. Implantation of ADSCs has been shown to yield beneficial effects on rat models of acute kidney injury (AKI). For example, ADSC treatment in an ischemia/ reperfusion (I/R)-induced rat model of AKI significantly decreased the number of apoptotic kidney cells and effectively restored urine protein and serum creatinine levels (Zhang et al., 2017). This finding suggested restoration of kidney function by ADSC treatment, and was consistent with the findings by Lin et al. (Lin et al., 2016). Moreover, ADSC treatment lead to markedly reduced expression levels of multiple pro-inflammatory cytokines, for example, IL-6, TNF- $\alpha$, and IFN- $\gamma$; however, was associated with elevated expression of anti-inflammatory cytokine, IL-10 (Zhang et al., 2017) at the mRNA level. Furthermore, ADSC treatment effectively ameliorated diabetic nephropathy by reducing oxidative stress and inflammatory cytokines levels (e.g. IL- 6 and TNF- $\alpha$ ), by mediating the inhibition of the pro-inflammatory p38 MAPK signaling pathway (Fang et al., 2012), a factor involved in the development of human diabetic nephropathy (Adhikary et al., 2004).

\section{Extracellular Vesicles and Renal Disease}

ADSC-EVs have been demonstrated to have a pivotal role in protection from the development of AKI. Zhu et al. studied downstream effects of using ADSC-EVs to prevent transition of $\mathrm{AKI}$ to $\mathrm{CKD}$, in a mouse model of renal I/R injury. The authors showed that mice treated with ADSC-EVs exhibited decreased renal I/R injury and increased proliferation of renal tubular epithelial cells, thus attenuating AKI (Zhu et al., 2017). Notably, treatment with ADSC-EVs resulted in upregulation of tubular SOX9 gene expression (Zhu et al., 2017), a key gene involved in renal repair and renal tubule epithelial cell regeneration (Kumar et al., 2015; Kang et al., 2016). Furthermore, reduced levels of the pro-fibrotic cytokine TGF$\beta 1$ were observed following the ADSC-EV treatment in the model, suggesting that the EVs inhibited TGF- $\beta 1$-induced renal fibrosis (Zhu et al., 2017), a key feature of CKD (Humphreys, 2018). Another study by Lin et al. demonstrated that inflammation, oxidative stress, apoptosis, fibrosis, and glomerular and renal tubular damage were mitigated by a combined treatment of ADSC-EVs and ADSCs in a rat model of renal I/R injury (Lin et al., 2016).

In diabetic nephropathy, a common variety of CKD due to impaired podocyte autophagy resulting from aberrant activation of the mTOR signaling pathway, a more recent study employed a spontaneous diabetic mouse model to assess the roles of
ADSC-EVs (Godel et al., 2011; Tagawa et al., 2016). It was demonstrated that serum creatinine and blood urea nitrogen and total urinary protein levels, indicators of renal dysfunction, were significantly reduced by ADSC-EVs in diabetic mice (Jin et al., 2019). This finding correlated with the study in AKI carried out by Lin et al. (Lin et al., 2016). Additionally, ADSC-EVs were shown to enhance autophagy (the body's clearance of cellular debris) and diminish podocyte apoptosis by restricting Smad1/ mTOR pathway activation via miR-486 (Jin et al., 2019). Activation of miR-486 is important as expression of miR-486 has been found to be down-regulated in diabetic patients when compared with non-diabetic individuals (Regmi et al., 2019), implying that miR-486-enriched ADSC-EVs could be a potential therapeutic for treating diabetic nephropathy. Overall, these findings suggest a therapeutic use for ADSCs in kidney diseases such as AKI and diabetic nephropathy, given their capacity to suppress oxidative stress and inflammation; and the possible additional future efficacy of ADSC-EV in AKI.

\section{ADSCs in Cancer}

A study using a xenograft mouse model of human breast cancer showed that human ADSCs promoted tumor growth when injected into a tumor. In contrast, ADSCs inhibited tumor growth when injected around the tumor (Illouz, 2014), suggesting distinct influences of ADSCs in different tumor microenvironments. A recent study by $\mathrm{Xu}$ et al. showed that ADSCs could promote metastases in mice xenografted with breast carcinoma through ADSC-released stem cell factormediated inhibition of miR20b, which in turn, lead to activation of the c-Kit/MAPK-p38/E2F1 signaling pathway and increased expression of HIF-1 $\alpha$ and VEGFA (Xu H. et al., 2019). Meanwhile, upregulation of miR20b reduced metastasis of 4T1 breast cancer cells to the lung, suggesting that miR20b acted as a tumor suppressor miRNA, and that ADSCs may be able to induce lung metastases in vivo, through miR-20b inhibition (Xu H. et al., 2019). In contrast, miR-20b was also shown to enhance breast cancer proliferation both in vitro and in vivo by inhibiting expression of the phosphatase and tensin homologue (PTEN) gene (Zhou et al., 2014), a well-known tumor suppressor gene involved in regulation of breast cancer cells (DeGraffenried et al., 2004). This discrepancy may be due to heterogenous roles of miR-20b in regulating breast cancer development in the presence of ADSCs and the ADSC secretome; or may be due to poor study design. Hence, before conclusions can be drawn, this area warrants further detailed studies. Controversies regarding the regulatory approval for use of fat grafting in a former or current tumor bed are summarized above and in (DeGraffenried et al., 2004).

\section{ADSC-Derived Extracellular Vesicles in Cancer}

Given the capacity of EVs to exert their effects by transferring proteins and RNA to target cells, the effects of EVs in promoting cancer progression has been studied extensively [reviewed in (Xu et al., 2018)]. It appears that ADSC-EVs have dual (or contradictory) functions in regulating tumorigenesis, both by promoting and inhibiting the growth of cancer cells. For instance, platelet-derived growth factors stimulate ADSCs to 
TABLE 3 | Completed and ongoing clinical trials of ADSCs.

\begin{tabular}{|c|c|c|c|c|c|}
\hline Diseases & Study phase & $\begin{array}{l}\text { Intervention or treat- } \\
\text { ment }\end{array}$ & $\begin{array}{l}\text { Autologous/Het- } \\
\text { erologous/Allo- } \\
\text { geneic }\end{array}$ & Key findings ADSC/EVs & Reference \\
\hline \multicolumn{6}{|l|}{ Continued } \\
\hline Fingertip injury & Pilot study & $\begin{array}{l}\text { Injections at the site of } \\
\text { injury }\end{array}$ & Autologous & $\begin{array}{l}\text { Accelerate wound healing process and } \\
\text { recovery of sensory function }\end{array}$ & $\begin{array}{l}\text { (Tarallo et al., } \\
\text { 2018) }\end{array}$ \\
\hline $\begin{array}{l}\text { Idiopathic pulmonary } \\
\text { fibrosis }\end{array}$ & $\mathrm{lb}$ & $\begin{array}{l}\text { Intravenous injections } \\
\text { of ADSC-derived SVF }\end{array}$ & Autologous & $\begin{array}{l}\text { Similar survival rates disease progression time } \\
\text { in untreated populations. } \\
\text { Fail to demonstrate any beneficial effect by } \\
\text { ADSC therapy }\end{array}$ & $\begin{array}{l}\text { (Ntolios et al., } \\
\text { 2018) }\end{array}$ \\
\hline $\begin{array}{l}\text { Refractory Perianal fistula } \\
\text { in Crohn's disease }\end{array}$ & III & $\begin{array}{l}\text { Local injections of } \\
\text { allogenic expanded } \\
\text { ADSCs }\end{array}$ & Autologous & $\begin{array}{l}\text { Remission of fistula openings and reduce } \\
\text { perianal disease (MRI) }\end{array}$ & $\begin{array}{l}\text { (Philandrianos } \\
\text { et al., 2018) }\end{array}$ \\
\hline $\begin{array}{l}\text { Secondary progressive } \\
\text { multiple sclerosis }\end{array}$ & $1 / 11$ & Intravenous injections & Autologous & $\begin{array}{l}\text { Safe \& feasible in patients. No significant } \\
\text { changes in safety parameters }\end{array}$ & (Fernandez et al., \\
\hline osteoarthritis & l/lla & Intra-articular injections & Autologous & $\begin{array}{l}\text { Safe and improved pain, function and cartilage } \\
\text { volume of knee joint }\end{array}$ & (Song et al., 2018) \\
\hline Diseases & & Study phase & $\begin{array}{l}\text { Intervention or } \\
\text { treatment }\end{array}$ & Autologous/Heterologous/Allogeneic & NCT number \\
\hline Chronic kidney diseases & & $|/| \mid$ & $\begin{array}{l}\text { Intravenous } \\
\text { injection }\end{array}$ & Autologous & NCT03939741 \\
\hline Diabetic foot ulcer & & $|/| \mid$ & $\begin{array}{l}\text { ADSC-enriched } \\
\text { fibrin gel }\end{array}$ & Autologous & NCT03865394 \\
\hline $\begin{array}{l}\text { Chronic obstructive } \\
\text { pulmonary disease }\end{array}$ & & 1 & $\begin{array}{l}\text { Intravenous } \\
\text { injection }\end{array}$ & Autologous & NCT02161744 \\
\hline $\begin{array}{l}\text { Isolated Articular Cartilage } \\
\text { Defects }\end{array}$ & & Unknown & $\begin{array}{l}\text { ADSC-enriched } \\
\text { acellular dermal } \\
\text { matrix }\end{array}$ & Autologous & NCT02090140 \\
\hline $\begin{array}{l}\text { Moderate to Severe } \\
\text { Chronic Kidney Disease }\end{array}$ & & $|/| \mid$ & Allogenic injection & Allogeneic & NCT02933827 \\
\hline Knee Osteoarthritis & & $|/| \mid$ & $\begin{array}{l}\text { Intra-articular } \\
\text { injection }\end{array}$ & Allogenic & NCT02784964 \\
\hline Scars or cutis laxa & & $|/| \mid$ & $\begin{array}{l}\text { Autologous } \\
\text { injection combined } \\
\text { with laser therapy }\end{array}$ & Autologous & NCT03887208 \\
\hline Stroke & & 1 & $\begin{array}{l}\text { Intravenous } \\
\text { injection }\end{array}$ & Unknown & NCT03570450 \\
\hline Knee osteoarthritis & & III & $\begin{array}{l}\text { Intra-articular } \\
\text { injection }\end{array}$ & Autologous & NCT03467919 \\
\hline Knee osteoarthritis & & Unknown & Transplantation & Autologous & NCT03014401 \\
\hline Vestibulodynia & & Unknown & Transplantation & Unknown & NCT03431779 \\
\hline Alopecia & & Unknown & Transplantation & Unknown & NCT03427905 \\
\hline $\begin{array}{l}\text { Ischemic Heart Disease } \\
\text { and Left Ventricular } \\
\text { Dysfunction }\end{array}$ & & I & $\begin{array}{l}\text { ADSC-enriched } \\
\text { VB-C01 collagen } \\
\text { patches }\end{array}$ & Allogeneic & NCT03746938 \\
\hline Facial Rejuvenation & & Unknown & $\begin{array}{l}\text { Intradermal } \\
\text { injection }\end{array}$ & Autologous & NCT03928444 \\
\hline
\end{tabular}

release EVs containing pro-angiogenic factors-such as Axl (Tanaka and Siemann, 2019), artemin (Banerjee et al., 2012) and stem cell factor (Zhang et al., 2000) - which have been shown to enhance angiogenesis in human microvascular endothelial cells (Lopatina et al., 2014). An in vitro study demonstrated that ADSC-EVs promoted migration and proliferation of MCF7 human breast carcinoma cells through activation of Wnt/ $\beta$-catenin signaling (Lin et al., 2013), although the involvement of angiogenesis was not assessed.

In contrast, there have been a few studies demonstrating that ADSC-EVs can act as tumor suppressors. For example, Takahara et al. demonstrated notable reduction in prostate cancer growth in tumor-bearing mice following ADSC-EVs treatment, an effect mediated via activation of the caspase-3/7 pro-apoptotic pathway, itself signaling via miR-145 (Takahara et al., 2016). The therapeutic potentials of microRNA-enriched EVs have also been explored in several tumor models. For example, miR-122 is highly expressed in the liver, and loss of miR-122 correlated with development of hepatocellular carcinoma (HCC) in mice (Tsai et al., 2012). Lou et al. demonstrated that miR-122 transfected ADSC-secreted EVs were rich in miR-122, and that uptake of these EVs by cultured HCC cells lead to increased chemosensitivity to chemotherapeutic agents and significant reduction in tumor growth in vivo (Lou et al., 2015). Similar 


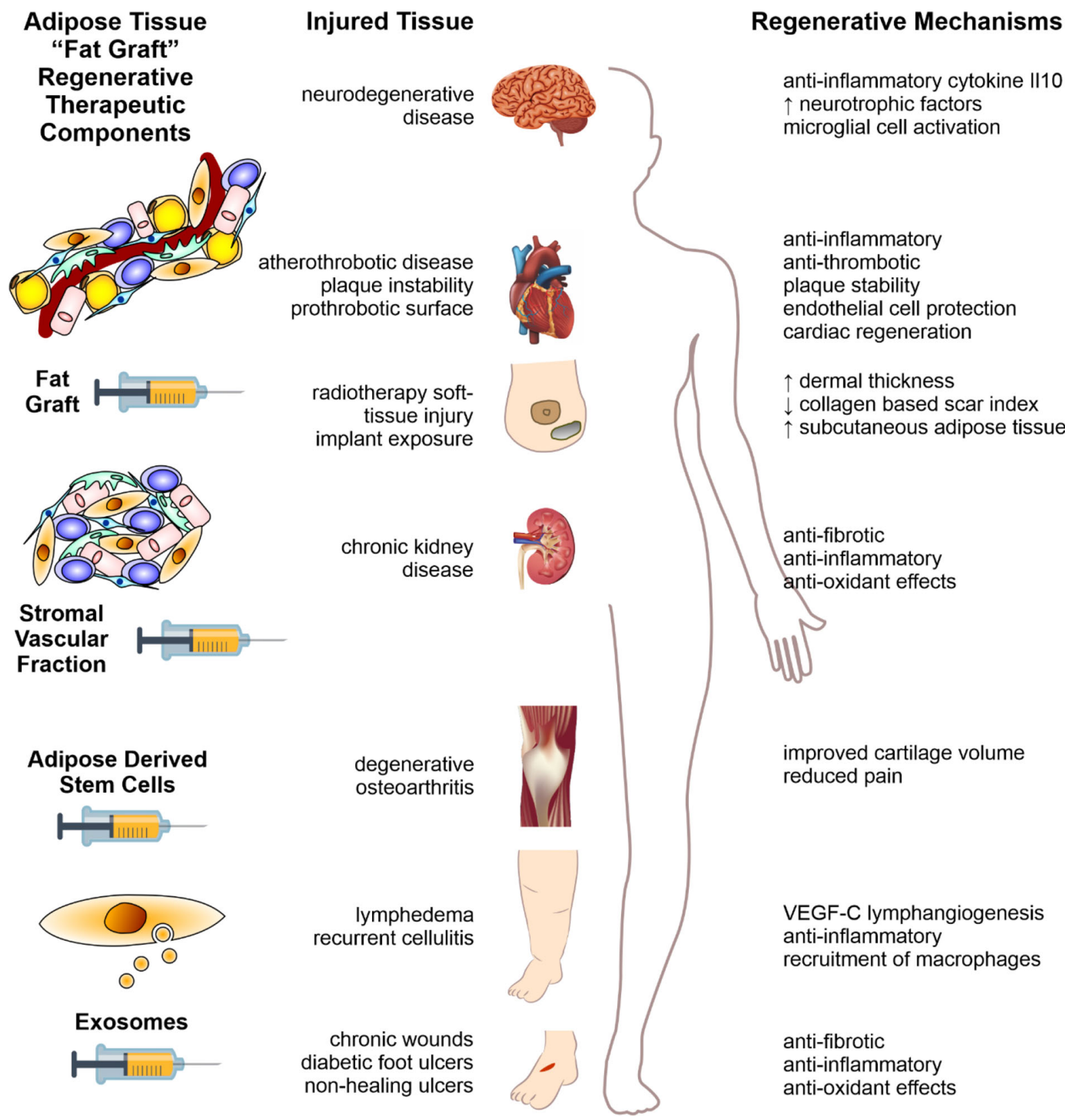

FIGURE 2 | Fat therapeutics of adipose tissue in human disease. Schematic summary of adipose tissue "fat graft" obtained via liposuction of subcutaneous fat. Refinement of this fat graft can has occurred at various levels from the acquisition of the rudimentary fat graft, further processed with digestion to obtain the stromal vascular fraction cell pellet, further refinement with extraction of ADSCs, and extracellular vesicle isolation (left column). Each of these components demonstrate significant therapeutic potential in reversing the pathology of human disease, across a range of body systems (middle column). The mechanisms by which these effects are mediated are illustrated in the right-hand column. Figure adapted from Shukla et al. (2015) under the CC-BY license (Shukla et al., 2015).

results were shown in a breast cancer study (O’Brien et al., 2018) employing ADSC-EVs enriched with miR-379, a tumor suppressor miRNA whose expression is down-regulated in breast cancer (Khan et al., 2013). It was found that the miR379-enriched ADSC-EVs significantly inhibited tumor growth without adverse effects in mice over the 6 weeks of monitoring
(O’Brien et al., 2018). These findings suggested a potential application of genetically engineered ADSCs to promote secretion of EVs encapsulated in tumor suppressor miRNAs may be a promising, novel strategy to treat cancer. However, whether ADSC-EVs have long-term therapeutic effects after withdrawal of administration is unknown. 


\section{Extracellular Vesicles in Cardiac Disease-Pathology and Cardio-Protection}

EVs derived from human ADSCs have been shown to demonstrate cardioprotective roles through their paracrine effects rather than the direct differentiation into cardiomyocytes. Cui et al. used a rodent myocardial I/R injury model to show that ADSC-EVs protected the myocardium from ischemia- or hypoxia- induced necrosis and apoptosis (Cui et al., 2017). Implantation of ADSCEVs in the rat model resulted in significant reduction in the levels of apoptotic proteins detected (e.g. Bax), and a significant increase in the expression of pro-survival proteins, including Bcl-2 and Cyclin D1 in rat myocardium (Cui et al., 2017). Further, ADSC-EVs exerted cardioprotective effects via activation of $\mathrm{Wnt} / \beta$-catenin signaling (Cui et al., 2017). Another experiment investigating treatment of a rodent model of myocardial infarction with ADSC-EVs profoundly improved cardiac dysfunction by suppressing cardiac apoptosis and fibrosis (Deng et al., 2019). Interestingly, ADSC-EVs promoted macrophage M2 polarization by activating the sphingosine 1-phosphate/sphingosine kinase 1/ sphingosine-1-phosphate receptor 1 signaling pathway, which inhibited inflammatory responses and reduced myocardial fibrosis, suggesting that ADSC-EVs may exert potential antiinflammatory effects (Deng et al., 2019). In addition, Luo et al. employed genetically modified ADSCs to overexpress miR-126 (a microRNA shown to exhibit cardioprotective effects in myocardial infarction) in EVs (Long et al., 2012; Fei et al., 2016). The miR-126enriched ADSC-EVs significantly decreased myocardial injury by inhibiting inflammation and fibrosis, and enhancing microvascular generation and migration in rats (Luo et al., 2017). Limitations of ADSC treatments for ischemia heart disease include low cardiac retention rates and insufficient concentrations and retained volumes (Li et al., 2019). Numerous clinical trials of ADSCsderived products have shown promise and an account of completed and ongoing clinical trials using ADSCs are summarized in Table 3.

\section{Summary of ADSC-Derived Clinical Trials}

The focus of this review is pre-clinical data supporting ADSCderived therapy; however, it is worth noting that several early clinical trials have been completed. Studies using non-adipose sourced stem cells are not discussed. Trials conducted to assess the benefit of ADSC-derived treatment of wounds, have only reached pilot study or phase I stage in simple cutaneous wounds (Kim et al., 2009; Holm et al., 2018); however, in Crohn's disease-related peri-anal fistulae, a phase III study (Panes et al., 2018) has shown good efficacy. Similarly, good efficacy has been shown in phase I and IIa studies involving treatment of osteoarthritis (Song et al., 2018) and phase III

\section{REFERENCES}

Adhikary, L., Chow, F., Nikolic-Paterson, D. J., Stambe, C., Dowling, J., Atkins, R. C., et al. (2004). Abnormal p38 mitogen-activated protein kinase signalling in human and experimental diabetic nephropathy. Diabetologia 47 (7), 1210-1222. doi: 10.1007/s00125-004-1437-0

AIHWA. (2012). Australian Institute of Health and Welfare \& Australasian Association of Cancer Registries (Canberra), 1-215. studies are ongoing at the time of writing (Table 3). Finally, promise has also been shown in central nervous system disease [phase I and II studies in multiple sclerosis (Fernandez et al., 2018)].

The dynamic nature of the field warrants close observation of the ongoing results of these clinical studies. It is hoped, however, that the application of genetically modified ADSC-derived small EVs may overcome issues encountered in trials of ADSCs and enhance our capacity to tailor and target future treatment approaches.

\section{CONCLUSION}

Fat has played a critical role in basic survival and function throughout the history of human evolution. Now, through evolving the role of fat, humankind may unlock critical answers that assist in novel therapeutic approaches to age-old human diseases; as well as those brought upon ourselves by the evolution of the modern lifestyle. The humble, and until recently rather unfashionable, fat cell may hold the secrets to combatting these diseases-be it through old-fashioned "en-bloc" delivery as raw fat graft, through more sophisticated ADSC-enrichment or cutting-edge discovery and harnessing of paracrine factors in exosomes and other EV types as depicted in Figure 2. Together, these insights and the putative treatment that result, may themselves form the cornerstone of the future treatment approaches in regenerative medicine.

\section{AUTHOR CONTRIBUTIONS}

LS, YY, RS, DG, and TK all contributed to conceptual and figure design, and writing and editing of manuscript. LS and DG contributed to figure creation and YY compiled tables.

\section{ACKNOWLEDGMENTS}

The authors acknowledge Janna Taylor for her expertise and professionalism in assistance with formatting and figure and table preparations. TK, RS, LS, and YY also thank the Wicking Trust, Stafford Fox Trust and McMullin Family Trust for their ongoing financial support of their work. This work was funded, in part, by the National Health \& Medical Research Council of Australia (project grant 1057741 and 1139489 to DG) and Helen Amelia Hanis Fellowship (to DG).

Akita, S., Yoshimoto, H., Ohtsuru, A., Hirano, A., and Yamashita, S. (2012). Autologous adipose-derived regenerative cells are effective for chronic intractable radiation injuries. Radiat. Prot. Dosimetry 151 (4), 656-660. doi: 10.1093/rpd/ncs176

Alvarez-Erviti, L., Seow, Y., Yin, H., Betts, C., Lakhal, S., and Wood, M. J. (2011). Delivery of siRNA to the mouse brain by systemic injection of targeted exosomes. Nat. Biotechnol. 29 (4), 341-345. doi: 10.1038/nbt.1807

Amosse, J., Durcin, M., Malloci, M., Vergori, L., Fleury, A., Gagnadoux, F., et al. (2018). Phenotyping of circulating extracellular vesicles (EVs) in obesity 
identifies large EVs as functional conveyors of Macrophage migration inhibitory factor. Mol. Metab. 18, 134-142. doi: 10.1016/j.molmet.2018.10.001

Antonyak, M. A., Cerione, R. A., and Natl Acad Sci, U. S. A. (2015). Emerging picture of the distinct traits and functions of microvesicles and exosomes. Proc. Natl. Acad. Sci. U. S. A 112 (12), 3589-3590. doi: 10.1073/pnas.1502590112

Authors on behalf of ICRP, Stewart, F. A., Akleyev, A. V., Hauer-Jensen, M., Hendry, J. H., Kleiman, N. J., et al. (2012). ICRP publication 118: ICRP statement on tissue reactions and early and late effects of radiation in normal tissues and organs-threshold doses for tissue reactions in a radiation protection context. Ann. ICRP 41 (1-2), 1-322. doi: 10.1016/j.icrp.2012.02.001

Avraham, T., Daluvoy, S., Zampell, J., Yan, A., Haviv, Y. S., Rockson, S. G., et al. (2010). Blockade of transforming growth factor-betal accelerates lymphatic regeneration during wound repair. Am. J. Pathol. 177 (6), 3202-3214. doi: 10.2353/ajpath.2010.100594

Baek, S. J., Kang, S. K., and Ra, J. C. (2011). In vitro migration capacity of human adipose tissue-derived mesenchymal stem cells reflects their expression of receptors for chemokines and growth factors. Exp. Mol. Med. 43 (10), 596-603. doi: $10.3858 / \mathrm{emm} .2011 .43 .10 .069$

Baer, P. C., and Geiger, H. (2012). Adipose-derived mesenchymal stromal/stem cells: tissue localization, characterization, and heterogeneity. Stem Cells Int. 2012, 812693. doi: 10.1155/2012/812693

Balaj, L., Atai, N. A., Chen, W., Mu, D., Tannous, B. A., Breakefield, X. O., et al. (2015). Heparin affinity purification of extracellular vesicles. Sci. Rep. 5, 10266. doi: 10.1038/srep 10266

Banerjee, A., Wu, Z. S., Qian, P. X., Kang, J., Liu, D. X., Zhu, T., et al. (2012). ARTEMIN promotes de novo angiogenesis in ER negative mammary carcinoma through activation of TWIST1-VEGF-A signalling. PloS One 7 (11), e50098. doi: 10.1371/journal.pone.0050098

Bensidhoum, M., Gobin, S., Chapel, A., Lemaitre, G., Bouet, S., Waksman, G., et al. (2005). Therapeutic effect of human mesenchymal stem cells in skin after radiation damage. J. Soc. Biol. 199 (4), 337-341. doi: 10.1051/jbio:2005035

Benvenuto, F., Ferrari, S., Gerdoni, E., Gualandi, F., Frassoni, F., Pistoia, V., et al. (2007). Human mesenchymal stem cells promote survival of $\mathrm{T}$ cells in a quiescent state. Stem Cells 25 (7), 1753-1760. doi: 10.1634/stemcells.2007-0068

Berg, J., Roch, M., Altschuler, J., Winter, C., Schwerk, A., Kurtz, A., et al. (2015). Human adipose-derived mesenchymal stem cells improve motor functions and are neuroprotective in the 6-hydroxydopamine-rat model for Parkinson's disease when cultured in monolayer cultures but suppress hippocampal neurogenesis and hippocampal memory function when cultured in spheroids. Stem Cell Rev. 11 (1), 133-149. doi: 10.1007/s12015-014-9551-y

Berman, S. B., and Hastings, T. G. (1999). Dopamine oxidation alters mitochondrial respiration and induces permeability transition in brain mitochondria: implications for Parkinson's disease. J. Neurochem. 73 (3), 1127-1137. doi: 10.1046/j.1471-4159.1999.0731127.x

Bhang, S. H., Cho, S. W., La, W. G., Lee, T. J., Yang, H. S., Sun, A. Y., et al. (2011). Angiogenesis in ischemic tissue produced by spheroid grafting of human adipose-derived stromal cells. Biomaterials 32 (11), 2734-2747. doi: 10.1016/ j.biomaterials.2010.12.035

Blaber, S. P., Webster, R. A., Hill, C. J., Breen, E. J., Kuah, D., Vesey, G., et al. (2012). Analysis of in vitro secretion profiles from adipose-derived cell populations. J. Transl. Med. 10, 172. doi: 10.1186/1479-5876-10-172

Brorson, H. (2003). [Liposuction of arm lymphoedema]. Handchir. Mikrochir. Plast. Chir. 35 (4), 225-232. doi: 10.1055/s-2003-42128

Bucan, V., Vaslaitis, D., Peck, C. T., Strauss, S., Vogt, P. M., and Radtke, C. (2019). Effect of Exosomes from rat Adipose-derived Mesenchymal stem cells on Neurite outgrowth and Sciatic nerve regeneration After Crush Injury. Mol. Neurobiol. 56 (3), 1812-1824. doi: 10.1007/s12035-018-1172-z

Butala, P., Sultan, S. M., Davidson, E. H., Crawford, J. L., Szpalski, C., Knobel, D., Allen, R. J., et al. (2010). Augmentation of fat graft survival with progenitor cell mobilization. Plast. Reconstr. Surg. 125 (6), 12. doi: 10.1097/01.prs.000037 1742.62300 .62

Caby, M. P., Lankar, D., Vincendeau-Scherrer, C., Raposo, G., and Bonnerot, C. (2005). Exosomal-like vesicles are present in human blood plasma. Int. Immunol. 17 (7), 879-887. doi: 10.1093/intimm/dxh267

Caplan, A. I., and Dennis, J. (2006). Mesenchymal stem cells as trophic mediators. J. Cell Biochem. 98 (5), 1076-1084. doi: 10.1002/jcb.20886

Carrade, D. D., Lame, M. W., Kent, M. S., Clark, K. C., Walker, N. J., and Borjesson, D. L. (2012). Comparative analysis of the immunomodulatory properties of Equine adult-derived Mesenchymal stem cells(). Cell Med. 4 (1), 1-11. doi: 10.3727/ 215517912 X647217

Carrasco-Ramirez, P., Greening, D. W., Andres, G., Gopal, S. K., MartinVillar, E., Renart, J., et al. (2016). Podoplanin is a component of extracellular vesicles that reprograms cell-derived exosomal proteins and modulates lymphatic vessel formation. Oncotarget 7 (13), 16070-16089. doi: 10.18632/oncotarget. 7445

Carraway, J. H., and Mellow, C. G. (1990). Syringe aspiration and fat concentration: a simple technique for autologous fat injection. Ann. Plast. Surg. 24 (3), 293-296. discussion; 297. doi: 10.1097/00000637-199003000-00018

Cawthorn, W. P., Scheller, E. L., and MacDougald, O. A. (2012). Adipose tissue stem cells meet preadipocyte commitment: going back to the future. J. Lipid Res. 53 (2), 227-246. doi: 10.1194/jlr.R021089

Chang, P., Qu, Y., Liu, Y., Cui, S., Zhu, D., Wang, H., et al. (2013). Multitherapeutic effects of human adipose-derived mesenchymal stem cells on radiation-induced intestinal injury. Cell Death Dis. 4, e685. doi: 10.1038/ cddis. 2013.178

Chaturvedi, R. K., Calingasan, N. Y., Yang, L., Hennessey, T., Johri, A., and Beal, M. F. (2010). Impairment of PGC-1alpha expression, neuropathology and hepatic steatosis in a transgenic mouse model of Huntington's disease following chronic energy deprivation. Hum. Mol. Genet. 19 (16), 3190-3205. doi: $10.1093 / \mathrm{hmg} / \mathrm{ddq} 229$

Chen, J., Ren, S., Duscher, D., Kang, Y., Liu, Y., Wang, C., et al. (2019). Exosomes from human adipose-derived stem cells promote sciatic nerve regeneration via optimizing Schwann cell function. J. Cell Physiol. 234 (12), 23097-23110. doi: $10.1002 /$ jcp. 28873

Chen, L., Tredget, E. E., Wu, P. Y., and Wu, Y. (2008). Paracrine factors of mesenchymal stem cells recruit macrophages and endothelial lineage cells and enhance wound healing. PloS One 3 (4), e1886. doi: 10.1371/ journal.pone.0001886

Chen, Y., Niu, Z., Xue, Y., Yuan, F., Fu, Y., and Bai, N. (2014). Improvement in the repair of defects in maxillofacial soft tissue in irradiated minipigs by a mixture of adipose-derived stem cells and platelet-rich fibrin. Br. J. Maxillofac. Surg. 52 (8), 740-745. doi: 10.1016/j.bjoms.2014.06.006

Choi, E. W., Seo, M. K., Woo, E. Y., Kim, S. H., Park, E. J., and Kim, S. (2018). Exosomes from human adipose-derived stem cells promote proliferation and migration of skin fibroblasts. Exp. Dermatol. 27 (10), 1170-1172. doi: 10.1111/ exd.13451

Cho, I. K., Yang, B., Forest, C., Qian, L., and Chan, A. W. S. (2019). Amelioration of Huntington's disease phenotype in astrocytes derived from iPSC-derived neural progenitor cells of Huntington's disease monkeys. PloS One 14 (3), e0214156. doi: 10.1371/journal.pone.0214156

Choi, H. S., Kim, H. J., Oh, J. H., Park, H. G., Ra, J. C., Chang, K. A., et al. (2015). Therapeutic potentials of human adipose-derived stem cells on the mouse model of Parkinson's disease. Neurobiol. Aging 36 (10), 2885-2892. doi: 10.1016/j.neurobiolaging.2015.06.022

Christianson, H. C., Svensson, K. J., van Kuppevelt, T. H., Li, J. P., and Belting, M. (2013). Cancer cell exosomes depend on cell-surface heparan sulfate proteoglycans for their internalization and functional activity. Proc. Natl. Acad. Sci. U. S. A 110 (43), 17380-17385. doi: 10.1073/pnas.1304266110

Clairembault, T., Kamphuis, W., Leclair-Visonneau, L., Rolli-Derkinderen, M., Coron, E., Neunlist, M., et al. (2014). Enteric GFAP expression and phosphorylation in Parkinson's disease. J. Neurochem. 130 (6), 805-815. doi: $10.1111 /$ inc. 12742

Claridge, B., Kastaniegaard, K., Stensballe, A., and Greening, D. W. (2019). Posttranslational and transcriptional dynamics - regulating extracellular vesicle biology. Expert Rev. Proteomics 16 (1), 17-31. doi: 10.1080/14789450.2019. 1551135

Clayton, A., Court, J., Navabi, H., Adams, M., Mason, M. D., Hobot, J. A., et al. (2001). Analysis of antigen presenting cell derived exosomes, based on immuno-magnetic isolation and flow cytometry. J. Immunol. Methods 247 (1-2), 163-174. doi: 10.1016/S0022-1759(00)00321-5

Coleman, S. R. (2001). Structural fat grafts: the ideal filler? Clin. Plast. Surg. 28 (1), 111-119.

Collawn, S. S., Banerjee, N. S., de la Torre, J., Vasconez, L., and Chow, L. T. (2012). Adipose-derived stromal cells accelerate wound healing in an organotypic raft culture model. Ann. Plast. Surg. 68 (5), 501-504. doi: 10.1097/ SAP.0b013e31823b69fc 
Colombo, M., Raposo, G., and Thery, C. (2014). Biogenesis, secretion, and intercellular interactions of exosomes and other extracellular vesicles. Аnnu. Rev. Cell Dev. Biol. 30, 255-289. doi: 10.1146/annurev-cellbio-101512-122326

Coren, L. V., Shatzer, T., and Ott, D. E. (2008). CD45 immunoaffinity depletion of vesicles from Jurkat $\mathrm{T}$ cells demonstrates that exosomes contain CD45: no evidence for a distinct exosome/HIV-1 budding pathway. Retrovirology 5, 64 . doi: $10.1186 / 1742-4690-5-64$

Crewe, C., Joffin, N., Rutkowski, J. M., Kim, M., Zhang, F., Towler, D. A., et al. (2018). An Endothelial-to-Adipocyte extracellular vesicle axis governed by metabolic state. Cell 175 (3), 695-708 e13. doi: 10.1016/j.cell.2018.09.005

Cui, L., Jeong, H., Borovecki, F., Parkhurst, C. N., Tanese, N., and Krainc, D. (2006). Transcriptional repression of PGC-1alpha by mutant huntingtin leads to mitochondrial dysfunction and neurodegeneration. Cell 127 (1), 59-69. doi: 10.1016/j.cell.2006.09.015

Cui, X., He, Z., Liang, Z., Chen, Z., Wang, H., and Zhang, J. (2017). Exosomes from Adipose-derived Mesenchymal stem cells protect the Myocardium against Ischemia/Reperfusion injury through Wnt/beta-Catenin signaling pathway. $J$. Cardiovasc. Pharmacol. 70 (4), 225-231. doi: 10.1097/FJC.0000000000000507

Czerny, A. (1895). Plastischer Ersatz der Brustdrüse durch ein Lipoma. Chir. Kongr. Verhandl. Dsch. Gesellch. Chir. 2 (216).

De Toro, J., Herschlik, L., Waldner, C., and Mongini, C. (2015). Emerging roles of exosomes in normal and pathological conditions: new insights for diagnosis and therapeutic applications. Front. Immunol. 6, 203. doi: 10.3389/ fimmu.2015.00203

Dean, J. P., Sprenger, C. C., Wan, J., Haugk, K., Ellis, W. J., Lin, D. W., et al. (2013). Response of the insulin-like growth factor (IGF) system to IGF-IR inhibition and androgen deprivation in a neoadjuvant prostate cancer trial: effects of obesity and androgen deprivation. J. Clin. Endocrinol. Metab. 98 (5), E820E828. doi: 10.1210/jc.2012-3856

DeGraffenried, L. A., Fulcher, L., Friedrichs, W. E., Grunwald, V., Ray, R. B., and Hidalgo, M. (2004). Reduced PTEN expression in breast cancer cells confers susceptibility to inhibitors of the PI3 kinase/Akt pathway. Ann. Oncol. 15 (10), 1510-1516. doi: 10.1093/annonc/mdh388

Delay, E., Garson, S., Tousson, G., and Sinna, R. (2009). Fat injection to the breast: technique, results, and indications based on 880 procedures over 10 years. Aesthet. Surg. J. 29 (5), 360-376. doi: 10.1016/j.asj.2009.08.010

Deng, S., Zhou, X., Ge, Z., Song, Y., Wang, H., Liu, X., et al. (2019). Exosomes from adipose-derived mesenchymal stem cells ameliorate cardiac damage after myocardial infarction by activating S1P/SK1/S1PR1 signaling and promoting macrophage M2 polarization. Int. J. Biochem. Cell Biol. 114, 105564. doi: 10.1016/j.biocel.2019.105564

Devalia, H. L., Mansfield, L., and Wound, J. (2008). Radiotherapy and wound healing. Int. Wound J. 5 (1), 40-44. doi: 10.1111/j.1742-481X.2007.00351.x

Dewhirst, M. W., Cao, Y., and Moeller, B. (2008). Cycling hypoxia and free radicals regulate angiogenesis and radiotherapy response. Nat. Rev. Cancer 8 (6), 425-437. doi: 10.1038/nrc2397

Dheen, S. T., Kaur, C., and Ling, E. A. (2007). Microglial activation and its implications in the brain diseases. Curr. Med. Chem. 14 (11), 1189-1197. doi: 10.2174/092986707780597961

Dominici, M., Le Blanc, K., Mueller, I., Slaper-Cortenbach, I., Marini, F., Krause, D., et al. (2006). Minimal criteria for defining multipotent mesenchymal stromal cells. The International society for cellular therapy position statement. Cytotherapy 8 (4), 315-317. doi: 10.1080/14653240600855905

Ebrahimian, T. G., Pouzoulet, F., Squiban, C., Buard, V., Andre, M., Cousin, B., et al. (2009). Cell therapy based on adipose tissue-derived stromal cells promotes physiological and pathological wound healing. Arterioscler. Thromb. Vasc. Biol. 29 (4), 503-510. doi: 10.1161/ATVBAHA.108.178962

Efimenko, A. Y., Kochegura, T. N., Akopyan, Z. A., and Parfyonova, Y. V. (2015). Autologous stem cell therapy: how aging and chronic diseases affect stem and progenitor cells. Biores Open Access 4 (1), 26-38. doi: 10.1089/biores.2014.0042

Eto, H., Suga, H., Inoue, K., Aoi, N., Kato, H., Araki, J., et al. (2012). Adipose injuryassociated factors mitigate hypoxia in ischemic tissues through activation of adipose-derived stem/progenitor/stromal cells and induction of angiogenesis. Am. J. Pathol. 178 (5), 2322-2332. doi: 10.1016/j.ajpath.2011.01.032

Eto, H., Kato, H., Suga, H., Aoi, N., Doi, K., Kuno, S., et al. (2011). The fate of adipocytes after nonvascularized fat grafting: evidence of early death and replacement of adipocytes. Plast. Reconstr. Surg. 129 (5), 1081-1092. doi: 10.1097/PRS.0b013e31824a2b19
Evans, J., Rai, A., Nguyen, H. P. T., Poh, Q. H., Elglass, K., Simpson, R. J., et al. (2019). In vitro human implantation model reveals a role for endometrial extracellular vesicles in embryo implantation: reprogramming the cellular and secreted proteome landscapes for bidirectional fetal-maternal communication. Proteomics 19 (23), e1800423. doi: 10.1002/pmic.201800423

Fang, Y., Tian, X., Bai, S., Fan, J., Hou, W., Tong, H., et al. (2012). Autologous transplantation of adipose-derived mesenchymal stem cells ameliorates streptozotocin-induced diabetic nephropathy in rats by inhibiting oxidative stress, pro-inflammatory cytokines and the p 38 MAPK signaling pathway. Int. J. Mol. Med. 30 (1), 85-92. doi: 10.3892/ijmm.2012.977

Fei, L., Zhang, J., Niu, H., Yuan, C., and Ma, X. (2016). Effects of Rosuvastatin and MiR-126 on Myocardial Injury Induced by Acute Myocardial Infarction in Rats: Role of Vascular Endothelial Growth Factor A (VEGF-A). Med. Sci. Monit. 22, 2324-2334. doi: 10.12659/MSM.896983

Feng, N., Jia, Y., and Huang, X. (2019). Exosomes from adipose-derived stem cells alleviate neural injury caused by microglia activation via suppressing NF-kB and MAPK pathway. J. Neuroimmunol. 334, 576996. doi: 10.1016/ j.jneuroim.2019.576996

Fernandez, O., Izquierdo, G., Fernandez, V., Leyva, L., Reyes, V., Guerrero, M., et al. (2018). Adipose-derived mesenchymal stem cells (AdMSC) for the treatment of secondary-progressive multiple sclerosis: A triple blinded, placebo controlled, randomized phase I/II safety and feasibility study. PloS One 13 (5), e0195891. doi: 10.1371/journal.pone.0195891

Flaherty, , S., Grijalva, A., Xu, X., Ables, E., Nomani, A., and Ferrante, A. (2019). A lipase-independent pathway of lipid release and immune modulation by adipocytes. Science 363 (6430), 989-993. doi: 10.1126/science.aaw2586

Forcheron, F., Agay, D., Scherthan, H., Riccobono, D., Herodin, F., Meineke, V., et al. (2012). Autologous adipocyte derived stem cells favour healing in a minipig model of cutaneous radiation syndrome. PloS One 7 (2), e31694. doi: 10.1371/journal.pone.0031694

Francois, S., Mouiseddine, M., Mathieu, N., Semont, A., Monti, P., Dudoignon, N., et al. (2007). Human mesenchymal stem cells favour healing of the cutaneous radiation syndrome in a xenogenic transplant model. Ann. Hematol. 86 (1), 18. doi: 10.1007/s00277-006-0166-5

Fraser, J. K., Wulur, I., Alfonso, Z., and Hedrick, M. H. (2006). Fat tissue: an underappreciated source of stem cells for biotechnology. Trends Biotechnol. 24 (4), 150-154. doi: 10.1016/j.tibtech.2006.01.010

Frazier, T. P., Gimble, J. M., Kheterpal, I., and Rowan, B. G. (2013). Impact of low oxygen on the secretome of human adipose-derived stromal/stem cell primary cultures. Biochimie 95 (12), 2286-2296. doi: 10.1016/ j.biochi.2013.07.011

Fry, D. E. (2017). Pressure irrigation of surgical incisions and traumatic wounds. Surg. Infect. (Larchmt) 18 (4), 424-430. doi: 10.1089/sur.2016.252

Fujimoto, T., and Parton, R. G. (2011). Not just fat: the structure and function of the lipid droplet. Cold Spring Harb. Perspect. Biol. 3 (3), 1-17. doi: 10.1101/ cshperspect.a004838

Geiger, A., Walker, A., and Nissen, E. (2015). Human fibrocyte-derived exosomes accelerate wound healing in genetically diabetic mice. Biochem. Biophys. Res. Commun. 467 (2), 303-309. doi: 10.1016/j.bbrc.2015.09.166

Geng, W., Tang, H., Luo, S., Lv, Y., Liang, D., Kang, X., et al. (2019). Exosomes from miRNA-126-modified ADSCs promotes functional recovery after stroke in rats by improving neurogenesis and suppressing microglia activation. Am. J. Transl. Res. 11 (2), 780-792.

Ghosh, A., Davey, M., Chute, I. C., Griffiths, S. G., Lewis, S., Chacko, S., et al. (2014). Rapid isolation of extracellular vesicles from cell culture and biological fluids using a synthetic peptide with specific affinity for heat shock proteins. PloS One 9 (10), el10443. doi: 10.1371/journal.pone.0110443

Gimble, J. M., Guilak, F., and Bunnell, B. A. (2011). Clinical and preclinical translation of cell-based therapies using adipose tissue-derived cells. Stem Cell Res. Ther. 1 (2), 19. doi: 10.1186/scrt19

Gimble, J. M., Bunnell, B. A., Chiu, E. S., and Guilak, F.. (2010). Concise review: adipose-derived stromal vascular fraction cells and stem cells: let's not get lost in translation. Stem Cells 29 (5), 749-754. doi: 10.1002/stem.629

Godel, M., Hartleben, B., Herbach, N., Liu, S., Zschiedrich, S., Lu, S., et al. (2011). Role of mTOR in podocyte function and diabetic nephropathy in humans and mice. J. Clin. Invest. 121 (6), 2197-2209. doi: 10.1172/JCI44774

Goh, Y. Y., Pal, M., Chong, H. C., Zhu, P., Tan, M. J., Punugu, L., et al. (2010). Angiopoietin-like 4 interacts with integrins betal and beta5 to modulate 
keratinocyte migration. Am. J. Pathol. 177 (6), 2791-2803. doi: 10.2353/ ajpath.2010.100129

Gould, S. J., and Raposo, G. (2013). As we wait: coping with an imperfect nomenclature for extracellular vesicles. J. Extracell. Vesicles 2, eCollection 2013. doi: $10.3402 /$ jev.v2i0.20389

Grazul-Bilska, A. T., Johnson, M. L., Bilski, J. J., Redmer, D. A., Reynolds, L. P., Abdullah, A., et al. (2003). Wound healing: the role of growth factors. Drugs Today (Barc) 39 (10), 787-800. doi: 10.1358/dot.2003.39.10.799472

Greenberger, J. S., and Epperly, M. (2009). Bone marrow-derived stem cells and radiation response. Semin. Radiat. Oncol. 19 (2), 133-139. doi: 10.1016/ j.semradonc.2008.11.006

Greening, D. W., and Simpson, R. J. (2018). Understanding extracellular vesicle diversity - current status. Expert Rev. Proteomics 15 (11), 887-910. doi: 10.1080/14789450.2018.1537788

Greening, D. W., Nguyen, H. P., Elgass, K., Simpson, R. J., and Salamonsen, L. A. (2016). Human endometrial exosomes contain hormone-specific cargo modulating trophoblast adhesive capacity: insights into endometrial-embryo interactions. Biol. Reprod. 94 (2), 38. doi: 10.1095/biolreprod.115.134890

Greening, D. W., Xu, R., Gopal, S. K., Rai, A., and Simpson, R. J. (2017). Proteomic insights into extracellular vesicle biology - defining exosomes and shed microvesicles. Expert Rev. Proteomics 14 (1), 69-95. doi: 10.1080/ 14789450.2017.1260450

Gronthos, S., Franklin, D. M., Leddy, H. A., Robey, P. G., Storms, R. W., and Gimble, J. M. (2001). Surface protein characterization of human adipose tissuederived stromal cells. J. Cell Physiol. 189 (1), 54-63. doi: 10.1002/jcp.1138

Gurtner, G. C., Werner, S., Barrandon, Y., and Longaker, M. T. (2008). Wound repair and regeneration. Nature 453 (7193), 314-321. doi: 10.1038/ nature 07039

Hamada, T., Matsubara, H., Yoshida, Y., Ugaji, S., Nomura, I., and Tsuchiya, H. (2019). Autologous adipose-derived stem cell transplantation enhances healing of wound with exposed bone in a rat model. PloS One 14 (5), e0214106. doi: 10.1371/journal.pone.0214106

Harfouche, G., and Martin, M. T. (2010). Response of normal stem cells to ionizing radiation: a balance between homeostasis and genomic stability. Mutat. Res. 704 (1-3), 167-174. doi: 10.1016/j.mrrev.2010.01.007

Haubner, F., Leyh, M., Ohmann, E., Pohl, F., Prantl, L., and Gassner, H. G. (2013). Effects of external radiation in a co-culture model of endothelial cells and adipose-derived stem cells. Radiat. Oncol. 8, 66. doi: 10.1186/1748-717X-8-66

Heo, S. C., Jeon, E. S., Lee, I. H., Kim, H. S., Kim, M. B., and Kim, J. H. (2011). Tumor necrosis factor-alpha-activated human adipose tissue-derived mesenchymal stem cells accelerate cutaneous wound healing through paracrine mechanisms. J. Invest. Dermatol. 131 (7), 1559-1567. doi: 10.1038/ jid.2011.64

Holm, J. S., Toyserkani, N. M., and Sorensen, J. A. (2018). Adipose-derived stem cells for treatment of chronic ulcers: current status. Stem Cell Res. Ther. 9 (1), 142. doi: 10.1186/s13287-018-0887-0

Hong, S. J., Lee, J. H., Hong, S. M., and Park, C. H. (2013). Enhancing the viability of fat grafts using new transfer medium containing insulin and beta-fibroblast growth factor in autologous fat transplantation. J. Plast. Reconstr. Aesthet. Surg. 63 (7), 1202-1208. doi: 10.1016/j.bjps.2009.05.040

Hong, S. J., Jia, S. X., Xie, P., Xu, W., Leung, K. P., Mustoe, T. A., et al. (2010). Topically delivered adipose derived stem cells show an activated-fibroblast phenotype and enhance granulation tissue formation in skin wounds. PloS One 8 (1), e55640. doi: 10.1371/journal.pone.0055640

Hsiao, S. T., Asgari, A., Lokmic, Z., Sinclair, R., Dusting, G. J., Lim, S. Y., et al. (2012). Comparative analysis of paracrine factor expression in human adult mesenchymal stem cells derived from bone marrow, adipose, and dermal tissue. Stem Cells Dev. 21 (12), 2189-2203. doi: 10.1089/ scd.2011.0674

Hu, L., Wang, J., and Zhou, X. (2016). Exosomes derived from human adipose mesenchymal stem cells accelerates cutaneous wound healing via optimizing the characteristics of fibroblasts. Sci. Rep. 6, 3. doi: 10.1038/srep32993

Huang, S. P., Huang, C. H., Shyu, J. F., Lee, H. S., Chen, S. G., Chan, J. Y., et al. (2013). Promotion of wound healing using adipose-derived stem cells in radiation ulcer of a rat model. J. BioMed. Sci. 20, 51. doi: 10.1186/14230127-20-51

Humphreys, B. D. (2018). Mechanisms of Renal Fibrosis. Annu. Rev. Physiol. 80, 309-326. doi: 10.1146/annurev-physiol-022516-034227
Illouz, Y. G. (1986). The fat cell "graft": a new technique to fill depressions. Plast. Reconstr. Surg. 78 (1), 122-123. doi: 10.1097/00006534-198607000-00028

Illouz, Y. G. (2014). Breast cancer treatment by adipose-derived stem cells: an experimental study. J. Stem Cells 9 (4), 211-217. doi: jsc.2015.9.4.211

Im, W., Ban, J., Lim, J., Lee, M., Lee, S. T., Chu, K., et al. (2013). Extracts of adipose derived stem cells slows progression in the R6/2 model of Huntington's disease. PloS One 8 (4), e59438. doi: 10.1371/journal.pone.0059438

Jeppesen, D. K., Fenix, A. M., Franklin, J. L., Higginbotham, J. N., Zhang, Q., Zimmerman, L. J., et al. (2019). Reassessment of exosome composition. Cell 177 (2), 428-445.e18. doi: 10.1016/j.cell.2019.02.029

Jessen, K. R., and Mirsky, R. (2019). The success and failure of the Schwann cell response to nerve injury. Front. Cell Neurosci. 13, 33. doi: 10.3389/ fncel.2019.00033

Ji, H., Greening, D. W., Barnes, T. W., Lim, J. W., Tauro, B. J., Rai, A., et al. (2014). Proteome profiling of exosomes derived from human primary and metastatic colorectal cancer cells reveal differential expression of key metastatic factors and signal transduction components. Proteomics 13 (10-11), 1672-1686. doi: 10.1002/pmic.201200562

Ji, H., Chen, M., Greening, D. W., He, W., Rai, A., Zhang, W., et al. (2013). Deep sequencing of RNA from three different extracellular vesicle (EV) subtypes released from the human LIM1863 colon cancer cell line uncovers distinct miRNA-enrichment signatures. PloS One 9 (10), el10314. doi: 10.1371/ journal.pone.0110314

Ji, R. C. (2007). Lymphatic endothelial cells, inflammatory lymphangiogenesis, and prospective players. Curr. Med. Chem. 14 (22), 2359-2368. doi: 10.2174/ 092986707781745541

Jiang, D., Qi, Y., Walker, N. G., Sindrilaru, A., Hainzl, A., Wlaschek, M., et al. (2013). The effect of adipose tissue derived MSCs delivered by a chemically defined carrier on full-thickness cutaneous wound healing. Biomaterials 34 (10), 2501-2515. doi: 10.1016/j.biomaterials.2012.12.014

Jin, Y., Yang, L., Zhang, Y., Gao, W., Yao, Z., Song, Y., et al. (2017). Effects of age on biological and functional characterization of adiposederived stem cells from patients with endstage liver disease. Mol. Med. Rep. 16 (3), 3510-3518. doi: 10.3892/mmr.2017.6967

Jin, J., Shi, Y., Gong, J., Zhao, L., Li, Y., He, Q., et al. (2019). Exosome secreted from adipose-derived stem cells attenuates diabetic nephropathy by promoting autophagy flux and inhibiting apoptosis in podocyte. Stem Cell Res. Ther. 10 (1), 95. doi: 10.1186/s13287-019-1177-1

Joseph, J. W., Koshkin, V., Zhang, C. Y., Wang, J., Lowell, B. B., Chan, C. B., et al. (2002). Uncoupling protein 2 knockout mice have enhanced insulin secretory capacity after a high-fat diet. Diabetes 51 (11), 3211-3219. doi: 10.2337/ diabetes.51.11.3211

Jung, H., Kim, H. H., Lee, D. H., Hwang, Y. S., Yang, H. C., and Park, J. C. (2011). Transforming growth factor-beta 1 in adipose derived stem cells conditioned medium is a dominant paracrine mediator determines hyaluronic acid and collagen expression profile. Cytotechnology 63 (1), 57-66. doi: 10.1007/s10616010-9327-4

Kang, H. M., Huang, S., Reidy, K., Han, S. H., Chinga, F., and Susztak, K. (2016). Sox9-Positive progenitor cells play a key role in renal tubule Epithelial regeneration in mice. Cell Rep. 14 (4), 861-871. doi: 10.1016/ j.celrep.2015.12.071

Kapur, S. K., and Katz, A. J. (2013). Review of the adipose derived stem cell secretome. Biochimie 95 (12), 2222-2228. doi: 10.1016/j.biochi.2013.06.001

Karathanasis V, P. S., Topouridou, K., Koliakou, E., Koliakos, G., and Demiri, E. (2013). Intradermal injection of GFP-producing adipose stromal cells promotes survival of random-pattern skin flaps in rats. Eur. J. Plast. Surg. 36 (5), 281-288. doi: 10.1007/s00238-013-0810-y

Karnoub, A. E., Dash, A. B., Vo, A. P., Sullivan, A., Brooks, M. W., Bell, G. W., et al. (2007). Mesenchymal stem cells within tumour stroma promote breast cancer metastasis. Nature 449 (7162), 557-563. doi: 10.1038/nature06188

Katsuda, T., Tsuchiya, R., Kosaka, N., Yoshioka, Y., Takagaki, K., Oki, K., et al. (2013). Human adipose tissue-derived mesenchymal stem cells secrete functional neprilysin-bound exosomes. Sci. Rep. 3, 1197. doi: 10.1038/srep01197

Keryer-Bibens, C., Pioche-Durieu, C., Villemant, C., Souquere, S., Nishi, N., Hirashima, M., et al. (2006). Exosomes released by EBV-infected nasopharyngeal carcinoma cells convey the viral latent membrane protein 1 and the immunomodulatory protein galectin 9. BMC Cancer 6, 283. doi: $10.1186 / 1471-2407-6-283$ 
Khan, S., Brougham, C. L., Ryan, J., Sahrudin, A., O’Neill, G., Wall, D., et al. (2013). miR-379 regulates cyclin B1 expression and is decreased in breast cancer. PloS One 8 (7), e68753. doi: 10.1371/journal. pone. 0068753

Khouri R, D. V. D. (2009). Breast reconstruction and augmentation using preexpansion and autologous fat transplantation. Clin. Plast. Surg. 36 (2), 269280. doi: 10.1016/j.cps.2008.11.009

Kilroy, G. E., Foster, S. J., Wu, X., Ruiz, J., Sherwood, S., Heifetz, A., et al. (2007). Cytokine profile of human adipose-derived stem cells: expression of angiogenic, hematopoietic, and pro-inflammatory factors. J. Cell Physiol. 212 (3), 702-709. doi: $10.1002 /$ jcp. 21068

Kim, W. S., Park, B. S., Kim, H. K., Park, J. S., Kim, K. J., Choi, J. S., et al. (2008). Evidence supporting antioxidant action of adipose-derived stem cells: protection of human dermal fibroblasts from oxidative stress. J. Dermatol. Sci. 49 (2), 133-142. doi: 10.1016/j.jdermsci.2007.08.004

Kim, W. S., Park, B. S., and Sung, J. H. (2009). The wound-healing and antioxidant effects of adipose-derived stem cells. Expert Opin. Biol. Ther. 9 (7), 879-887. doi: 10.1517/14712590903039684

Kim, W. S., Park, B. S., and Sung, J. H. (2009). Antiwrinkle effect of adiposederived stem cell: activation of dermal fibroblast by secretory factors. J. Dermatol. Sci. 53 (2), 96-102. doi: 10.1016/j.jdermsci.2008.08.007

Kim, S., Chang, K. A., Kim, J., Park, H. G., Ra, J. C., Kim, H. S., et al. (2012). The preventive and therapeutic effects of intravenous human adipose-derived stem cells in Alzheimer's disease mice. PloS One 7 (9), e45757. doi: 10.1371/ journal.pone. 0045757

Kim, H., Hyun, M. R., and Kim, S. W. (2019). The effect of Adipose-derived stem cells on wound healing: comparison of methods of application. Stem Cells Int. 2019, 2745640. doi: 10.1155/2019/2745640

Koga, K., Matsumoto, K., Akiyoshi, T., Kubo, M., Yamanaka, N., Tasaki, A., et al. (2005). Purification, characterization and biological significance of tumorderived exosomes. Anticancer Res. 25 (6A), 3703-3707.

Kojima, T., Kanemaru, S., Hirano, S., Tateya, I., Ohno, S., Nakamura, T., et al. (2011). Regeneration of radiation damaged salivary glands with adiposederived stromal cells. Laryngoscope 121 (9), 1864-1869. doi: 10.1002/ lary. 22080

Kolle, S. F., Fischer-Nielsen, A., Mathiasen, A. B., Elberg, J. J., Oliveri, R. S., Glovinski, P. V., et al. (2013). Enrichment of autologous fat grafts with ex-vivo expanded adipose tissue-derived stem cells for graft survival: a randomised placebo-controlled trial. Lancet 382 (9898), 1113-1120. doi: 10.1016/S01406736(13)61410-5

Krumboeck, A., Giovanoli, P., and Plock, J. A. (2013). Fat grafting and stem cell enhanced fat grafting to the breast under oncological aspectsrecommendations for patient selection. Breast 22 (5), 579-584. doi: 10.1016/ j.breast.2013.05.006

Kumar, S., Liu, J., Pang, P., Krautzberger, A. M., Reginensi, A., Akiyama, H., et al. (2015). Sox9 activation highlights a cellular pathway of Renal repair in the acutely injured Mammalian kidney. Cell Rep. 12 (8), 1325-1338. doi: 10.1016/ j.celrep.2015.07.034

Kunigelis, K. E., and Graner, M. W. (2015). The Dichotomy of tumor exosomes (TEX) in cancer immunity: is it all in the ConTEXt? Vaccines (Basel) 3 (4), 1019-1051. doi: 10.3390/vaccines3041019

Kuo, Y. R., Wang, C. T., Cheng, J. T., Kao, G. S., Chiang, Y. C., and Wang, C. J. (2016). Adipose-derived stem cells accelerate diabetic wound healing through the induction of autocrine and paracrine effects. Cell Transplant. 25 (1), 71-81. doi: $10.3727 / 096368915 X 687921$

Lai, C. P., Kim, E. Y., Badr, C. E., Weissleder, R., Mempel, T. R., Tannous, B. A., et al. (2015). Visualization and tracking of tumour extracellular vesicle delivery and RNA translation using multiplexed reporters. Nat. Commun. 6, 7029. doi: 10.1038 /ncomms 8029

Lawson, C. D., and Ridley, A. J. (2018). Rho GTPase signaling complexes in cell migration and invasion. J. Cell Biol. 217 (2), 447-457. doi: 10.1083/ jcb.201612069

Lee, B. B., and Villavicencio, J. L. (2010). Primary lymphoedema and lymphatic malformation: are they the two sides of the same coin? Eur. J. Vasc. Endovasc. Surg. 39 (5), 646-653. doi: 10.1016/j.ejvs.2010.01.018

Lee, S. T., Chu, K., Jung, K. H., Im, W. S., Park, J. E., Lim, H. C., et al. (2009). Slowed progression in models of Huntington disease by adipose stem cell transplantation. Ann. Neurol. 66 (5), 671-681. doi: 10.1002/ana.21788
Lee, M. J., Kim, J., Kim, M. Y., Bae, Y. S., Ryu, S. H., Lee, T. G., et al. (2010). Proteomic analysis of tumor necrosis factor-alpha-induced secretome of human adipose tissue-derived mesenchymal stem cells. J. Proteome Res. 9 (4), 1754-1762. doi: 10.1021/pr900898n

Lee, S. H., Jin, S. Y., Song, J. S., Seo, K. K., and Cho, K. H. (2012). Paracrine effects of adipose-derived stem cells on keratinocytes and dermal fibroblasts. Ann. Dermatol. 24 (2), 136-143. doi: 10.5021/ad.2012.24.2.136

Lee, M., Liu, T., Im, W., and Kim, M. (2018). Exosomes from adipose-derived stem cells ameliorate phenotype of Huntington's disease in vitro model. Eur. J. Neurosci. 44 (4), 2114-2119. doi: 10.1111/ejn.13275

Lee, M., Ban, J. J., Yang, S., Im, W., and Kim, M. (2016). The exosome of adiposederived stem cells reduces beta-amyloid pathology and apoptosis of neuronal cells derived from the transgenic mouse model of Alzheimer's disease. Brain Res. 1691, 87-93. doi: 10.1016/j.brainres.2018.03.034

Li, P., Kaslan, M., Lee, S. H., Yao, J., and Gao, Z. (2017). Progress in exosome isolation techniques. Theranostics 7 (3), 789-804. doi: 10.7150/thno.18133

Li, X., Ma, T., Sun, J., Shen, M., Xue, X., Chen, Y., et al. (2019). Harnessing the secretome of adipose-derived stem cells in the treatment of ischemic heart diseases. Stem Cell Res. Ther. 10 (1), 196. doi: 10.1186/s13287-019-1289-7

Lin, C. S., Xin, Z. C., Deng, C. H., Ning, H., Lin, G., and Lue, T. F. (2010). Defining adipose tissue-derived stem cells in tissue and in culture. Histol. Histopathol. 25 (6), 807-815. doi: 10.14670/HH-25.807

Lin, R., Wang, S., and Zhao, R. C. (2013). Exosomes from human adipose-derived mesenchymal stem cells promote migration through Wnt signaling pathway in a breast cancer cell model. Mol. Cell Biochem. 383 (1-2), 13-20. doi: 10.1007/ s11010-013-1746-z

Lin, K. C., Yip, H. K., Shao, P. L., Wu, S. C., Chen, K. H., Chen, Y. T., et al. (2016). Combination of adipose-derived mesenchymal stem cells (ADMSC) and ADMSC-derived exosomes for protecting kidney from acute ischemia-reperfusion injury. Int. J. Cardiol. 216, 173-185. doi: 10.1016/j.ijcard.2016.04.061

Locke, M., Windsor, J., and Dunbar, P. R. (2009). Human adipose-derived stem cells: isolation, characterization and applications in surgery. ANZ J. Surg. 79 (4), 235-244. doi: 10.1111/j.1445-2197.2009.04852.x

Long, G., Wang, F., Duan, Q., Chen, F., Yang, S., Gong, W., et al. (2012). Human circulating microRNA-1 and microRNA-126 as potential novel indicators for acute myocardial infarction. Int. J. Biol. Sci. 8 (6), 811-818. doi: $10.7150 /$ ijbs. 4439

Lopatina, T., Bruno, S., Tetta, C., Kalinina, N., Porta, M., and Camussi, G. (2014). Platelet-derived growth factor regulates the secretion of extracellular vesicles by adipose mesenchymal stem cells and enhances their angiogenic potential. Cell Commun. Signal 12, 26. doi: 10.1186/1478$811 \mathrm{X}-12-26$

Lou, G., Song, X., Yang, F., Wu, S., Wang, J., Chen, Z., et al. (2015). Exosomes derived from miR-122-modified adipose tissue-derived MSCs increase chemosensitivity of hepatocellular carcinoma. J. Hematol. Oncol. 8, 122. doi: 10.1186/s13045-015-0220-7

Lu, F., Mizuno, H., Uysal, C. A., Cai, X., Ogawa, R., and Hyakusoku, H. (2009). Improved viability of random pattern skin flaps through the use of adiposederived stem cells. Plast. Reconstr. Surg. 121 (1), 50-58. doi: 10.1097/ 01.prs.0000293876.10700.b8

Lu, F., Li, J., Gao, J., Ogawa, R., Ou, C., Yang, B., et al (2008). Improvement of the survival of human autologous fat transplantation by using VEGF-transfected adipose-derived stem cells. Plast. Reconstr. Surg. 124 (5), 1437-1446. doi: 10.1097/PRS.0b013e3181babbb6

Luo, Q., Guo, D., Liu, G., Chen, G., Hang, M., and Jin, M. (2017). Exosomes from MiR-126-Overexpressing Adscs Are Therapeutic in Relieving Acute Myocardial Ischaemic Injury. Cell Physiol. Biochem. 44 (6), 2105-2116. doi: $10.1159 / 000485949$

Marigo, I., and Dazzi, F. (2011). The immunomodulatory properties of mesenchymal stem cells. Semin. Immunopathol. 33 (6), 593-602. doi: 10.1007/s00281-011-0267-7

Mathieu, M., Martin-Jaular, L., Lavieu, G., and Thery, C. (2019). Specificities of secretion and uptake of exosomes and other extracellular vesicles for cell-tocell communication. Nat. Cell Biol. 21 (1), 9-17. doi: 10.1038/s41556-0180250-9

Mathivanan, S., Lim, J. W., Tauro, B. J., Ji, H., Moritz, R. L., and Simpson, R. J. (2010). Proteomics analysis of A33 immunoaffinity-purified exosomes released 
from the human colon tumor cell line LIM1215 reveals a tissue-specific protein signature. Mol. Cell. Proteomics 9 (2), 197-208. doi: 10.1074/mcp.M900152MCP200

Matsuda, K., Falkenberg, K. J., Woods, A. A., Choi, Y. S., Morrison, W. A., Dilley, R. J., and Eng Part, A. (2013). Adipose-derived stem cells promote angiogenesis and tissue formation for in vivo tissue engineering. Tissue Eng. Part A 19 (1112), 1327-1335. doi: 10.1089/ten.tea.2012.0391

Matsumoto, D., Sato, K., Gonda, K., Takaki, Y., Shigeura, T., Sato, T., et al. (2006). Cell-assisted lipotransfer: supportive use of human adipose-derived cells for soft tissue augmentation with lipoinjection. Tissue Eng. 12 (12), 3375-3382. doi: $10.1089 /$ ten.2006.12.3375

Mazzola, R. F., Cantarella, G., Torretta, S., Sbarbati, A., Lazzari, L., and Pignataro, L. (2011). Autologous fat injection to face and neck: from soft tissue augmentation to regenerative medicine. Acta Otorhinolaryngol. Ital. 31 (2), 59-69.

McGregor, M. M., and Nelson, A. B.(2019). Circuit mechanisms of Parkinson's disease. Neuron 101 (6), 1042-1056. doi: 10.1016/j.neuron.2019.03.004

Meligy, F. Y., Elgamal, D. A., Abd Allah, E. S. H., Idriss, N. K., Ghandour, N. M., Bayoumy, E. M. R., et al. (2019). Testing alternatives: the use of adiposederived mesenchymal stem cells to slow neurodegeneration in a rat model of Parkinson's disease. Mol. Biol. Rep. 46 (6), 5841-5858. doi: 10.1007/s11033019-05018-9

Mercier, S. K., Donaghy, H., Botting, R. A., Turville, S. G., Harman, A. N., Nasr, N., et al. (2013). The microvesicle component of HIV-1 inocula modulates dendritic cell infection and maturation and enhances adhesion to and activation of T lymphocytes. PloS Pathog. 9 (10), e1003700. doi: 10.1371/ annotation/059beb14-db84-4836-9fef-ec351946025a

Mizuno, H. (2009). Adipose-derived stem cells for tissue repair and regeneration: ten years of research and a literature review. J. Nippon Med. Sch. 76 (2), 56-66. doi: $10.1272 /$ jnms.76.56

Morad, G., Carman, C. V., Hagedorn, E. J., Perlin, J. R., Zon, L. I., Mustafaoglu, N., et al. (2019). Tumor-derived extracellular vesicles breach the intact blood-brain barrier via Transcytosis. ACS Nano. 13 (12), 13853-13865. doi: 10.1021/ acsnano.9b04397

Mouiseddine, M., Francois, S., Semont, A., Sache, A., Allenet, B., Mathieu, N., et al. (2007). Human mesenchymal stem cells home specifically to radiation-injured tissues in a non-obese diabetes/severe combined immunodeficiency mouse model. Br. J. Radiol. 80 (Spec No 1), S49-S55. doi: 10.1259/bjr/25927054

Nambu, M., Ishihara, M., Kishimoto, S., Yanagibayashi, S., Yamamoto, N., Azuma, R., et al. (2011). Stimulatory effect of Autologous Adipose tissue-derived stromal cells in an Atelocollagen matrix on wound healing in diabetic $\mathrm{db} / \mathrm{db}$ mice. J. Tissue Eng. 2011, 158105. doi: 10.4061/2011/158105

Navabi, H., Croston, D., Hobot, J., Clayton, A., Zitvogel, L., Jasani, B., et al. (2005). Preparation of human ovarian cancer ascites-derived exosomes for a clinical trial. Blood Cells Mol. Dis. 35 (2), 149-152. doi: 10.1016/j.bcmd.2005.06.008

Neuber, F. (1893). Fat transplantation. Chir. Kongr. Verhandl. Dsch. Gesellch. Chir. 20 (66).

Neuhof, H., and Hirshfeld, S. (1923). The transplantation of tissues (New York: Appleton), 1-297.

Nie, C., Yang, D., Xu, J., Si, Z., Jin, X., and Zhang, J. (2011). Locally administered adipose-derived stem cells accelerate wound healing through differentiation and vasculogenesis. Cell Transplant. 20 (2), 205-216. doi: 10.3727/096368910X520065

Nishimura, T., Hashimoto, H., Nakanishi, I., and Furukawa, M. (2000). Microvascular angiogenesis and apoptosis in the survival of free fat grafts. Laryngoscope 110 (8), 1333-1338. doi: 10.1097/00005537-200008000-00021

Ntolios, P., Manoloudi, E., Tzouvelekis, A., Bouros, E., Steiropoulos, P., Anevlavis, S., et al. (2018). Longitudinal outcomes of patients enrolled in a phase Ib clinical trial of the adipose-derived stromal cells-stromal vascular fraction in idiopathic pulmonary fibrosis. Clin. Respir. J. 12 (6), 2084-2089. doi: 10.1111/crj.12777

O’Brien, K. P., Khan, S., Gilligan, K. E., Zafar, H., Lalor, P., Glynn, C., et al. (2018). Employing mesenchymal stem cells to support tumor-targeted delivery of extracellular vesicle (EV)-encapsulated microRNA-379. Oncogene 37 (16), 2137-2149. doi: 10.1038/s41388-017-0116-9

Ogata, F., Fujiu, K., Matsumoto, S., Nakayama, Y., Shibata, M., Oike, Y., et al. (2016). Excess Lymphangiogenesis cooperatively induced by Macrophages and CD4(+) T cells drives the Pathogenesis of Lymphedema. J. Invest. Dermatol. 136 (3), 706-714. doi: 10.1016/j.jid.2015.12.001

Ohnishi, S., Sumiyoshi, H., Kitamura, S., and Nagaya, N. (2007). Mesenchymal stem cells attenuate cardiac fibroblast proliferation and collagen synthesis through paracrine actions. FEBS Lett. 581 (21), 3961-3966. doi: 10.1016/ j.febslet.2007.07.028

Oksvold, M. P., Kullmann, A., Forfang, L., Kierulf, B., Li, M., Brech, A., et al. (2014). Expression of B-cell surface antigens in subpopulations of exosomes released from B-cell lymphoma cells. Clin. Ther. 36 (6), 847-862e1. doi: 10.1016/j.clinthera.2014.05.010

Ostermann, M., and Joannidis, M. (2016). Acute kidney injury 2016: diagnosis and diagnostic workup. Crit. Care 20 (1), 299. doi: 10.1186/s13054-016-1478-z

Pallua, N., Pulsfort, A. K., Suschek, C., and Wolter, T. P. (2009). Content of the growth factors bFGF, IGF-1, VEGF, and PDGF-BB in freshly harvested lipoaspirate after centrifugation and incubation. Plast. Reconstr. Surg. 123 (3), 826-833. doi: 10.1097/PRS.0b013e318199ef31

Panes, J., Garcia-Olmo, D., Van Assche, G., Colombel, J. F., Reinisch, W., Baumgart, D. C., et al. (2018). Long-term efficacy and safety of stem cell therapy (Cx601) for complex Perianal Fistulas in patients with Crohn's disease. Gastroenterology 154 (5), 1334-1342 e4. doi: 10.1053/j.gastro.2017.12.020

Philandrianos, C., Serrero, M., Grimaud, F., Magalon, J., Visee, C., Velier, M., et al. (2018). First clinical case report of local microinjection of autologous fat and adipose-derived stromal vascular fraction for perianal fistula in Crohn's disease. Stem Cell Res. Ther. 9 (1), 4. doi: 10.1186/s13287-017-0736-6

Phinney, D. G., and Prockop, D. J. (2007). Concise review: mesenchymal stem/ multipotent stromal cells: the state of transdifferentiation and modes of tissue repair-current views. Stem Cells 25 (11), 2896-2902. doi: 10.1634/ stemcells.2007-0637

Piccinno, M. S., Veronesi, E., Loschi, P., Pignatti, M., Murgia, A., Grisendi, G., et al. (2013). Adipose stromal/stem cells assist fat transplantation reducing necrosis and increasing graft performance. Apoptosis 18 (10), 1274-1289. doi: 10.1007/ s10495-013-0878-7

Pitt, J. M., Andre, F., Amigorena, S., Soria, J. C., Eggermont, A., Kroemer, G., et al. (2016). Dendritic cell-derived exosomes for cancer therapy. J. Clin. Invest. 126 (4), 1224-1232. doi: 10.1172/JCI81137

Prowle, J. R., Ishikawa, K., May, C. N., and Bellomo, R.(2010). Renal plasma flow and glomerular filtration rate during acute kidney injury in man. Ren. Fail 32 (3), 349-355. doi: 10.3109/08860221003611695

Rafieian-Kopaei, M. (2013). Medicinal plants for renal injury prevention. J. Renal Inj. Prev. 2 (2), 63-65. doi: 10.12861/jrip.2013.21

Rai, A., Greening, D. W., Chen, M., Xu, R., Ji, H., and Simpson, R. J.(2019). Exosomes derived from human primary and metastatic colorectal cancer cells contribute to functional heterogeneity of activated fibroblasts by reprogramming their proteome. Proteomics 19 (8), e1800148. doi: 10.1002/ pmic. 201800148

Rajabzadeh, N., Fathi, E., and Farahzadi, R. (2019). Stem cell-based regenerative medicine. Stem Cell Invest. 6, 19. doi: 10.21037/sci.2019.06.04

Raposio, E., and Ciliberti, R. (2017). Clinical use of adipose-derived stem cells: European legislative issues. Ann. Med. Surg. (Lond.) 24, 61-64. doi: 10.1016/ j.amsu.2017.11.002

Raposo, G., and Stoorvogel, W. (2013). Extracellular vesicles: exosomes, microvesicles, and friends. J. Cell Biol. 200 (4), 373-383. doi: 10.1083/ jcb. 201211138

Regmi, A., Liu, G., Zhong, X., Hu, S., Ma, R., Gou, L., et al. (2019). Evaluation of Serum microRNAs in patients with diabetic kidney disease: a nested casecontrolled study and bioinformatics analysis. Med. Sci. Monit. 25, 1699-1708. doi: 10.12659/MSM.913265

Rehman, J., Traktuev, D., Li, J., Merfeld-Clauss, S., Temm-Grove, C. J., Bovenkerk, J. E., et al. (2004). Secretion of angiogenic and antiapoptotic factors by human adipose stromal cells. Circulation 109 (10), 1292-1298. doi: 10.1161/ 01.CIR.0000121425.42966.F1

Reiner, A. T., Witwer, K. W., van Balkom, B. W. M., de Beer, J., Brodie, C., Corteling, R. L., et al. (2017). Concise review: developing best-practice models for the therapeutic use of extracellular vesicles. Stem Cells Transl. Med 6 (8), 1730-1739. doi: 10.1002/sctm.17-0055

Ren, S., Chen, J., Duscher, D., Liu, Y., Guo, G., Kang, Y., et al. (2019). Microvesicles from human adipose stem cells promote wound healing by optimizing cellular functions via AKT and ERK signaling pathways. Stem Cell Res. Ther. 10 (1), 47. doi: 10.1186/s13287-019-1152-x

Rigotti, G., Marchi, A., Galie, M., Baroni, G., Benati, D., Krampera, M., et al. (2007). Clinical treatment of radiotherapy tissue damage by lipoaspirate transplant: a healing process mediated by adipose-derived adult stem cells. 
Plast. Reconstr. Surg. 119 (5), 1409-1422. discussion 1423-4. doi: 10.1097/ 01.prs.0000256047.47909.71

Rigotti, G., Marchi, A., Stringhini, P., Baroni, G., Galie, M., Molino, A. M., et al. (2010). Determining the oncological risk of autologous lipoaspirate grafting for post-mastectomy breast reconstruction. Aesthetic. Plast. Surg. 34 (4), 475-480. doi: 10.1007/s00266-010-9481-2

Rodriguez-Menocal, L., Salgado, M., Ford, D., and Van Badiavas, E. (2012). Stimulation of skin and wound fibroblast migration by mesenchymal stem cells derived from normal donors and chronic wound patients. Stem Cells Transl. Med. 1 (3), 221-229. doi: 10.5966/sctm.2011-0029

Rohrich, R. J., Sorokin, E. S., and Brown, S. A. (2004). In search of improved fat transfer viability: a quantitative analysis of the role of centrifugation and harvest site. Plast. Reconstr. Surg. 113 (1), 391-395. discussion 396-7. doi: 10.1097/01.PRS.0000097293.56504.00

Romagnoli, G. G., Zelante, B. B., Toniolo, P. A., Migliori, I. K., and Barbuto, J. A. (2014). Dendritic cell-derived exosomes may be a tool for cancer immunotherapy by converting tumor cells into immunogenic targets. Front. Immunol. 5, 692. doi: 10.3389/fimmu.2014.00692

Ross, R. J., Shayan, R., Mutimer, K. L., and Ashton, M. W. (2014). Autologous fat grafting: current state of the art and critical review. Ann. Plast. Surg. 73 (3), 352-357. doi: 10.1097/SAP.0b013e31827aeb51

Rupp, A. K., Rupp, C., Keller, S., Brase, J. C., Ehehalt, R., Fogel, M., et al. (2011). Loss of EpCAM expression in breast cancer derived serum exosomes: role of proteolytic cleavage. Gynecol. Oncol. 122 (2), 437-446. doi: 10.1016/j.ygyno.2011.04.035

Saijo, H., Suzuki, K., Yoshimoto, H., Imamura, Y., Yamashita, S., and Tanaka, K. (2019). Paracrine effects of Adipose-derived stem cells promote Lymphangiogenesis in irradiated Lymphatic Endothelial cells. Plast. Reconstr. Surg. 143 (6), 1189e-1200e. doi: 10.1097/PRS.0000000000005669

Shayan, R., Achen, M. G., and Stacker, S. A. (2006). Lymphatic vessels in cancer metastasis: bridging the gaps. Carcinogenesis 27 (9), 1729-1738. doi: 10.1093/ carcin/bgl031

Shimizu, Y., Shibata, R., Shintani, S., Ishii, M., and Murohara, T.(2012). Therapeutic lymphangiogenesis with implantation of adipose-derived regenerative cells. J. Am. Heart Assoc. 1 (4), e000877. doi: 10.1161/JAHA.112.000877

Shoshani, O., Livne, E., Armoni, M., Shupak, A., Berger, J., Ramon, Y., et al. (2005). The effect of interleukin- 8 on the viability of injected adipose tissue in nude mice. Plast. Reconstr. Surg. 115 (3), 853-859. doi: 10.1097/01.PRS.0000153036.71928.30

Shukla, L., Morrison, W. A., and Shayan, R. (2015). Adipose-derived stem cells in radiotherapy injury: a new frontier. Front. Surg. 2, 1. doi: 10.3389/fsurg.2015.00001

Simonacci, F., Bertozzi, N., Grieco, M. P., Grignaffini, E., and Raposio, E. (2016). Autologous fat transplantation for breast reconstruction: a literature review. Ann. Med. Surg. (Lond.) 12, 94-100. doi: 10.1016/j.amsu.2016.11.012

Song, Y., Du, H., Dai, C., Zhang, L., Li, S., Hunter, D. J., et al. (2018). Human adipose-derived mesenchymal stem cells for osteoarthritis: a pilot study with long-term follow-up and repeated injections. Regener. Med. 13 (3), 295-307. doi: 10.2217/rme-2017-0152

Stone, H. B., Coleman, C. N., Anscher, M. S., and McBride, W. H. (2003). Effects of radiation on normal tissue: consequences and mechanisms. Lancet Oncol. 4 (9), 529-536. doi: 10.1016/S1470-2045(03)01191-4

Strioga, M., Viswanathan, S., Darinskas, A., Slaby, O., and Michalek, J. (2012). Same or not the same? Comparison of adipose tissue-derived versus bone marrow-derived mesenchymal stem and stromal cells. Stem Cells Dev. 21 (14), 2724-2752. doi: 10.1089/scd.2011.0722

Suga, H., Eto, H., Aoi, N., Kato, H., Araki, J., Doi, K., et al. (2010). Adipose tissue remodeling under ischemia: death of adipocytes and activation of stem/ progenitor cells. Plast. Reconstr. Surg. 126 (6), 1911-1923. doi: 10.1097/ PRS.0b013e3181f4468b

Sultan, S. M., Stern, C. S., Allen, R., Thanik, V. D., Chang, C. C., Nguyen, P. D., et al. (2011). Human fat grafting alleviates radiation skin damage in a murine model. Plast. Reconstr. Surg. 128 (2), 363-372. doi: 10.1097/PRS.0b013e31821e6e90

Tabit, C. J., Slack, G. C., Fan, K., Wan, D. C., and Bradley, J. P. (2012). Fat grafting versus adipose-derived stem cell therapy: distinguishing indications, techniques, and outcomes. Aesthetic. Plast. Surg. 36 (3), 704-713. doi: 10.1007/s00266-011-9835-4

Tagawa, A., Yasuda, M., Kume, S., Yamahara, K., Nakazawa, J., Chin-Kanasaki, M., et al. (2016). Impaired Podocyte Autophagy Exacerbates Proteinuria in Diabetic Nephropathy. Diabetes 65 (3), 755-767. doi: 10.2337/db15-0473

Takahara, K., Ii, M., Inamoto, T., Nakagawa, T., Ibuki, N., Yoshikawa, Y., et al. (2016). microRNA-145 mediates the inhibitory effect of Adipose tissue-derived stromal cells on prostate cancer. Stem Cells Dev. 25 (17), 1290-1298. doi: $10.1089 / \mathrm{scd} .2016 .0093$

HTanaka, M., and Siemann, D. W. (2019). Axl signaling is an important mediator of tumor angiogenesis. Oncotarget 10 (30), 2887-2898. doi: 10.18632/oncotarget.26882

Tarallo, M., Fino, P., Ribuffo, D., Casella, D., Toscani, M., Spalvieri, C., et al. (2018). Liposuction aspirate fluid Adipose-derived stem cell injection and secondary healing in fingertip injury: a pilot study. Plast. Reconstr. Surg. 142 (1), 136-147. doi: 10.1097/PRS.0000000000004506

Tauro, B. J., Greening, D. W., Mathias, R. A., Ji, H., Mathivanan, S., Scott, A. M., et al. (2012). Comparison of ultracentrifugation, density gradient separation, and immunoaffinity capture methods for isolating human colon cancer cell line LIM1863-derived exosomes. Methods 56 (2), 293-304. doi: 10.1016/ j.ymeth.2012.01.002

Thanik, V. D., Chang, C. C., Lerman, O. Z., Allen, R., Nguyen, P. D., Saadeh, P. B., et al. (2009). A murine model for studying diffusely injected human fat. Plast. Reconstr. Surg. 124 (1), 74-81. doi: 10.1097/PRS.0b013e3181a80509

Thery, C., Witwer, K. W., Aikawa, E., Alcaraz, M. J., Anderson, J. D., Andriantsitohaina, R. et al. (2018). Minimal information for studies of extracellular vesicles 2018 (MISEV2018): a position statement of the International Society for Extracellular Vesicles and update of the MISEV2014 guidelines. J. Extracell. Vesicles 7 (1), 1535750. doi: 10.1080/20013078.2018.1535750

Thomou, T., Mori, M. A., Dreyfuss, J. M., Konishi, M., Sakaguchi, M., Wolfrum, C., et al. (2017). Adipose-derived circulating miRNAs regulate gene expression in other tissues. Nature 542 (7642), 450-455. doi: 10.1038/nature21365

Tian, H., and Li, W. (2017). Dendritic cell-derived exosomes for cancer immunotherapy: hope and challenges. Ann. Transl. Med. 5 (10), 221. doi: 10.21037/atm.2017.02.23

Tremolada, C., Palmieri, G., and Ricordi, C. (2010). Adipocyte transplantation and stem cells: plastic surgery meets regenerative medicine. Cell Transplant. 19 (10), 1217-1223. doi: 10.3727/096368910X507187

Tricarico, C., Clancy, J., and D'Souza-Schorey, C. (2017). Biology and biogenesis of shed microvesicles. Small GTPases. 8 (4), 220-232. doi: 10.1080/21541248.2016.1215283

Trojahn Kolle, S. F., Oliveri, R. S., Glovinski, P. V., Elberg, J. J., Fischer-Nielsen, A., and Drzewiecki, K. T. (2012). Importance of mesenchymal stem cells in autologous fat grafting: a systematic review of existing studies. J. Plast. Surg. Handb. Surg. 46 (2), 59-68. doi: 10.3109/2000656X.2012.668326

Tsai, W. C., Hsu, S. D., Hsu, C. S., Lai, T. C., Chen, S. J., Shen, R., et al. (2012). MicroRNA-122 plays a critical role in liver homeostasis and hepatocarcinogenesis. J. Clin. Invest. 122 (8), 2884-2897. doi: 10.1172/JCI63455

Uysal, A. C., Mizuno, H., Tobita, M., Ogawa, R., and Hyakusoku, H. (2009). The effect of adipose-derived stem cells on ischemia-reperfusion injury: immunohistochemical and ultrastructural evaluation. Plast. Reconstr. Surg. 124 (3), 804-815. doi: 10.1097/PRS.0b013e3181b17bb4

van Niel, G., D'Angelo, G., and Raposo, G. (2018). Shedding light on the cell biology of extracellular vesicles. Nat. Rev. Mol. Cell Biol. 19 (4), 213-228. doi: 10.1038/nrm.2017.125

von Heimburg, D., Hemmrich, K., Zachariah, S., Staiger, H., and Pallua, N. (2005). Oxygen consumption in undifferentiated versus differentiated adipogenic mesenchymal precursor cells. Respir. Physiol. Neurobiol. 146 (2-3), 107-116. doi: 10.1016/j.resp.2004.12.013

Walter, M., Liang, S., Ghosh, S., Hornsby, P. J., and Li, R. (2009). Interleukin 6 secreted from adipose stromal cells promotes migration and invasion of breast cancer cells. Oncogene 28 (30), 2745-2755. doi: 10.1038/onc.2009.130

Wang, W. Z., Fang, X. H., Williams, S. J., Stephenson, L. L., Baynosa, R. C., Wong, N., et al. (2013). Analysis for apoptosis and necrosis on adipocytes, stromal vascular fraction, and adipose-derived stem cells in human lipoaspirates after liposuction. Plast. Reconstr. Surg. 131 (1), 77e-85e. doi: 10.1097/PRS.0b013e3 $182729 \mathrm{ff7}$

Wang, L., Hu, L., Zhou, X., Xiong, Z., Zhang, C., Shehada, H. M. A., et al. (2017). Exosomes secreted by human adipose mesenchymal stem cells promote scarless cutaneous repair by regulating extracellular matrix remodelling. Sci. Rep. 7 (1), 13321. doi: 10.1038/s41598-017-12919-x

Wiley, R. D., and Gummuluru, S. (2006). Immature dendritic cell-derived exosomes can mediate HIV-1 trans infection. Proc. Natl. Acad. Sci. U. S. A 103 (3), 738-743. doi: 10.1073/pnas.0507995103

Willms, E., Johansson, H. J., Mager, I., Lee, Y., Blomberg, K. E., Sadik, M., et al. (2016). Cells release subpopulations of exosomes with distinct molecular and biological properties. Sci. Rep. 6, 22519. doi: 10.1038/srep22519 
Wu, J., Chen, K., Zhang, F., Jin, J., Zhang, N., Li, D., et al. (2017). Overcoming Linsitinib intrinsic resistance through inhibition of nuclear factor-kappaB signaling in esophageal squamous cell carcinoma. Cancer Med. 6 (6), 13531361. doi: $10.1002 / \mathrm{cam} 4.1068$

Wu, Y. Y., Jiao, Y. P., Xiao, L. L., Li, M. M., Liu, H. W., Li, S. H., et al. (2018). Experimental study on effects of Adipose-derived stem cell-seeded silk Fibroin Chitosan film on wound healing of a diabetic rat model. Ann. Plast. Surg. 80 (5), 572-580. doi: 10.1097/SAP.0000000000001355

Xu, R., Greening, D. W., Rai, A., Ji, H., and Simpson, R. J. (2015). Highly-purified exosomes and shed microvesicles isolated from the human colon cancer cell line LIM1863 by sequential centrifugal ultrafiltration are biochemically and functionally distinct. Methods 87, 11-21. doi: 10.1016/j.ymeth.2015.04.008

Xu, R., Greening, D. W., Zhu, H. J., Takahashi, N., and Simpson, R. J. (2016). Extracellular vesicle isolation and characterization: toward clinical application. J. Clin. Invest. 126 (4), 1152-1162. doi: 10.1172/JCI81129

Xu, R., Rai, A., Chen, M., Suwakulsiri, W., Greening, D. W., and Simpson, R. J. (2018). Extracellular vesicles in cancer - implications for future improvements in cancer care. Nat. Rev. Clin. Oncol. 15 (10), 617-638. doi: 10.1038/s41571-018-0036-9

Xu, R., Greening, D. W., Chen, M., Rai, A., Ji, H., Takahashi, N., et al (2019). Surfaceome of exosomes secreted from the colorectal cancer cell line SW480: Peripheral and integral membrane proteins analyzed by proteolysis and TX114. Proteomics 19 (18), e1700453. doi: 10.1002/pmic.201700453

Xu, H., Li, W., Luo, S., Yuan, J., and Hao, L. (2019). Adipose derived stem cells promote tumor metastasis in breast Cancer cells by stem cell factor inhibition of miR20b. Cell Signal 62, 109350. doi: 10.1016/j.cellsig.2019.109350

Yan, A., Avraham, T., Zampell, J. C., Haviv, Y. S., Weitman, E., and Mehrara, B. J. (2011). Adipose-derived stem cells promote lymphangiogenesis in response to VEGF-C stimulation or TGF-beta1 inhibition. Future Oncol. 7 (12), 14571473. doi: $10.2217 /$ fon.11.121

Yan, Y., Ma, T., Gong, K., Ao, Q., Zhang, X., and Gong, Y. (2014). Adipose-derived mesenchymal stem cell transplantation promotes adult neurogenesis in the brains of Alzheimer's disease mice. Neural Regener. Res. 9 (8), 798-805. doi: 10.4103/1673-5374.131596

Yang, Y., Cai, Y., Zhang, Y., Liu, J., and Xu, Z. (2018). Exosomes secreted by Adipose-derived stem cells contribute to Angiogenesis of brain microvascular Endothelial cells following Oxygen-Glucose deprivation in vitro through MicroRNA-181b/TRPM7 Axis. J. Mol. Neurosci. 65 (1), 74-83. doi: 10.1007/ s12031-018-1071-9

Yim N, R. S., Choi, K., Lee, K. R., Lee, S., Choi, H., Kim, J., et al. (2016). Exosome engineering for efficient intracellular delivery of solube proteins using optically reversible protein-protein interaction module. Nat. Commun. 7. doi: 10.1038/ ncomms 12277

Yoo, C. E., Kim, G., Kim, M., Park, D., Kang, H. J., Lee, M., et al. (2012). A direct extraction method for microRNAs from exosomes captured by immunoaffinity beads. Anal. Biochem. 431 (2), 96-98. doi: 10.1016/j.ab.2012.09.008

Yoshimura, K., Shigeura, T., Matsumoto, D., Sato, T., Takaki, Y., Aiba-Kojima, E., et al. (2006). Characterization of freshly isolated and cultured cells derived from the fatty and fluid portions of liposuction aspirates. J. Cell Physiol. 208 (1), 64-76. doi: 10.1002/jcp.20636

Yoshimura, K., Sato, K., Aoi, N., Kurita, M., Hirohi, T., and Harii, K. (2008). Cellassisted lipotransfer for cosmetic breast augmentation: supportive use of adipose-derived stem/stromal cells. Aesthetic. Plast. Surg. 32 (1), 48-55. discussion 56-7. doi: 10.1007/s00266-007-9019-4

Yoshimura, K., Suga, H., and Eto, H. (2009). Adipose-derived stem/progenitor cells: roles in adipose tissue remodeling and potential use for soft tissue augmentation. Regener. Med. 4 (2), 265-273. doi: 10.2217/17460751.4.2.265

Yoshimura K, A. Y. (2010). Fat injection to the breasts: cosmetic augmentation, implant replacement, inborn deformity, and reconstruction after mastectomy. Aesthetic. Reconstr. Surg. 405-420.

Yuan, Y., Gao, J., Liu, L., and Lu, F. (2013). Role of adipose-derived stem cells in enhancing angiogenesis early after aspirated fat transplantation: induction or differentiation? Cell Biol. Int. 37 (6), 547-550. doi: 10.1002/cbin.10068

Zhang, W., Stoica, G., Tasca, S. I., Kelly, K. A., and Meininger, C. J. (2000). Modulation of tumor angiogenesis by stem cell factor. Cancer Res. 60 (23), 6757-6762.

Zhang, Y., Daquinag, A. C., Amaya-Manzanares, F., Sirin, O., Tseng, C., and Kolonin, M. G. (2012). Stromal progenitor cells from endogenous adipose tissue contribute to pericytes and adipocytes that populate the tumor microenvironment. Cancer Res. 72 (20), 5198-5208. doi: 10.1158/0008-5472.CAN-12-0294

Zhang, B., Wang, M., Gong, A., Zhang, X., Wu, X., Zhu, Y., et al. (2015). HucMSCExosome mediated-Wnt4 signaling is required for cutaneous wound healing. Stem Cells 33 (7), 2158-2168. doi: 10.1002/stem.1771

Zhang, J., Guan, J., Niu, X., Hu, G., Guo, S., Li, Q., et al. (2015). Exosomes released from human induced pluripotent stem cells-derived MSCs facilitate cutaneous wound healing by promoting collagen synthesis and angiogenesis. J. Transl. Med. 13, 49. doi: 10.1186/s12967-015-0417-0

Zhang, J. B., Wang, X. Q., Lu, G. L., Huang, H. S., and Xu, S. Y. (2017). Adiposederived mesenchymal stem cells therapy for acute kidney injury induced by ischemia-reperfusion in a rat model. Clin. Exp. Pharmacol. Physiol. 44 (12), 1232-1240. doi: 10.1111/1440-1681.12811

Zhang, H., Freitas, D., Kim, H. S., Fabijanic, K., Li, Z., Chen, H., et al. (2018). Identification of distinct nanoparticles and subsets of extracellular vesicles by asymmetric flow field-flow fractionation. Nat. Cell Biol. 20 (3), 332-343. doi: 10.1038/s41556-018-0040-4

Zhang, L., Zhang, B., Liao, B., Yuan, S., Liu, Y., Liao, Z., et al. (2019). Platelet-rich plasma in combination with adipose-derived stem cells promotes skin wound healing through activating Rho GTPase-mediated signaling pathway. Am. J. Transl. Res. 11 (7), 4100-4112.

Zhou, W., Shi, G., Zhang, Q., Wu, Q., Li, B., and Zhang, Z. (2014). MicroRNA$20 \mathrm{~b}$ promotes cell growth of breast cancer cells partly via targeting phosphatase and tensin homologue (PTEN). Cell Biosci. 4 (1), 62. doi: 10.1186/2045-3701-4-62

Zhu, M., Zhou, Z., Chen, Y., Schreiber, R., Ransom, J. T., Fraser, J. K., et al. (2010). Supplementation of fat grafts with adipose-derived regenerative cells improves long-term graft retention. Ann. Plast. Surg. 64 (2), 222-228. doi: 10.1097/ SAP.0b013e31819ae05c

Zhu, F., Chong Lee Shin, O. L. S., Pei, G., Hu, Z., Yang, J., Zhu, H., et al. (2017). Adipose-derived mesenchymal stem cells employed exosomes to attenuate AKI-CKD transition through tubular epithelial cell dependent Sox9 activation. Oncotarget 8 (41), 70707-70726. doi: 10.18632/oncotarget.19979

Zhu Y, L. T., Song, K., Fan, X., Ma, X., and Cui, Z. (2008). Adipose-derived stem cell: a better stem cell than BMSC. Cell Biochem. Funct. 26 (6), 664-675. doi: 10.1002/cbf.1488

Zimmerlin, L., Donnenberg, A. D., Rubin, J. P., Basse, P., Landreneau, R. J., and Donnenberg, V.S. (2011). Regenerative therapy and cancer: in vitro and in vivo studies of the interaction between adipose-derived stem cells and breast cancer cells from clinical isolates. Tissue Eng. Part A 17 (1-2), 93-106. doi: 10.1089/ ten.tea.2010.0248

Zografou, A., Tsigris, C., Papadopoulos, O., Kavantzas, N., Patsouris, E., Donta, I., et al. (2011). Improvement of skin-graft survival after autologous transplantation of adipose-derived stem cells in rats. J. Plast. Reconstr. Aesthet. Surg. 64 (12), 1647-1656. doi: 10.1016/j.bjps.2011.07.009

Zuk, P. A., Zhu, M., Ashjian, P., De Ugarte, D. A., Huang, J. I., Mizuno, H., Alfonso, Z. C., et al. (2001). Multilineage cells from human adipose tissue: implications for cell-based therapies. Tissue Eng. 7 (2), 211-228. doi: 10.1089/ 107632701300062859

Zuk PA1, Z. M., Ashjian, P., De Ugarte, D. A., Huang, J. I., Mizuno, H., Alfonso, Z. C., et al. (2002). Human adipose tissue is a source of multipotent stem cells. Mol. Biol. Cell 13 (12), 4279-4295. doi: 10.1091/mbc.E02-02-0105

Zuk, P. (2013). Adipose-derived stem cells in tissue regeneration: a review. ISRN Stem Cells 2013 (5), 1-35. doi: 10.1155/2013/713959

Conflict of Interest: The authors declare that the research was conducted in the absence of any commercial or financial relationships that could be construed as a potential conflict of interest.

Copyright (c) 2020 Shukla, Yuan, Shayan, Greening and Karnezis. This is an openaccess article distributed under the terms of the Creative Commons Attribution License (CC BY). The use, distribution or reproduction in other forums is permitted, provided the original author(s) and the copyright owner(s) are credited and that the original publication in this journal is cited, in accordance with accepted academic practice. No use, distribution or reproduction is permitted which does not comply with these terms. 